\title{
Zalecenia PTFM dotyczące prowadzenia kontroli ułożenia pacjentów leczonych wiązkami zewnętrznymi. Część II - Metody
}

\author{
Paweł Kukołowicz ${ }^{1, a}$ \\ ${ }^{I}$ Centrum Onkologii-Instytut im. Marii Sklodowskiej-Curie, Zakład Fizyki Medycznej \\ ${ }^{a}$ E-mail address:p.kukolowicz@zfm.coi.pl
}

\section{Wprowadzenie}

Przygotowanie i przeprowadzenie leczenia z użyciem wiązek zewnętrznych promieniowania jonizującego wymaga szczególnej staranności. Zarówno prawdopodobieństwo wyleczenie miejscowego $z$ nowotworu, jak i prawdopodobieństwo uszkodzenia narządów, czy też tkanek zależy silnie od podanej dawki promieniowania (od dawki pochłoniętej). Nawet niewielkie zmiany dawki pochłoniętej przez guz nowotworowy, czy też przez tkanki zdrowe mogą prowadzić bądź to do znaczącego zmniejszenia prawdopodobieństwa miejscowego wyleczenia, gdy podana zostanie niższa dawka od zleconej przez lekarza radioterapeutę, bądź to do wzrostu ryzyka wystąpienia uszkodzeń popromiennych, gdy podana dawka jest wyższa od zleconej przez lekarza. Zasadniczo można wyróżnić dwie grupy przyczyn powodujących podanie innej dawki od zleconej: 1) błędy dozymetryczne, 2) błędy geometryczne.

Do najważniejszych błędów dozymetrycznych należą: błędy pomiarowe, błędy obliczeniowe i nieprawidłowo działająca aparatura terapeutyczna. Warto zwrócić uwagę, że pewna grupa błędów obliczeniowych ma swoje źródło w błędach pomiarowych. Wynika to $\mathrm{z}$ faktu, że plany leczenia są przygotowywane $\mathrm{z}$ użyciem komputerowych systemów planowania leczenia, do których wprowadzane są dane wejściowe uzyskiwane poprzez pomiar.

Błędy geometryczne mogą powstać na etapie przygotowania leczenia $\mathrm{z}$ użyciem promieniowania jonizującego lub $\mathrm{w}$ trakcie jego trwania. Inne położenie napromienianej objętości tarczowej względem wiązki terapeutycznej niż określone na etapie planowania leczenia prowadzi nieuchronnie do podania niższej dawki w objętości tarczowej i zwykle wyższej dawki w narządach i tkankach krytycznych. W odróżnieniu od konsekwencji błędów dozymetrycznych, które, o ile wcześnie wykryte, mogą być przynajmniej w pewnym zakresie naprawione, korekta błędów geometrycznych w większości klinicznych sytuacji nie jest możliwa.

W celu zilustrowania błędnego określenia geometrii napromieniania przeanalizujmy sytuację przedstawioną na rycinie 1.1. Pacjent $\mathrm{z}$ nowotworem gruczołu krokowego po prostatektomii jest leczony techniką trójpolową, polem przednim i dwoma bocznymi klinowanymi polami przeciwległymi. Izocentrum planu leczenia jest określane poprzez znaczniki zewnętrzne (tatuaże) umieszczone na skórze pacjenta. Wskutek napięcia mięśni tatuaże na skórze przesunęły się względem układu kostnego. Zmiana położenia znaczników zewnętrznych spowodowała, że centratory laserowe wskazały inny punkt wewnątrz ciała pacjenta niż ten, który wyznaczono jako izocentrum na etapie planowania leczenia. W konsekwencji granice wiązek terapeutycznych obejmują inny obszar tkanek niż wyznaczony w trakcie planowania leczenia. Właściwe izocentrum i obszar wyznaczony w trakcie planowania leczenia oznaczono jako „PI - zaplanowane izocentrum”. Realizowane izocentrum wiązek oznaczono jako „RI - realizowane izocentrum”. W konsekwencji, jeżeli przyjmiemy założenie, że objętość tarczowa nie zmienia swojego położenia względem układu kostnego, górna część objętości tarczowej nie otrzyma pełnej dawki terapeutycznej oraz pewna objętość tkanek prawidłowych, w szczególności fragment jelita grubego (narząd krytyczny) otrzyma wyższą dawkę od tej, jaką obliczono w systemie planowania leczenia.

Kontrola ułożenia pacjenta ma na celu wykrycie geometrycznych błędów realizacji leczenia na wczesnym etapie jego realizacji i ewentualne wprowadzenie takich zmian, aby geometria napromieniania była jak najbliższa zaplanowanej. 

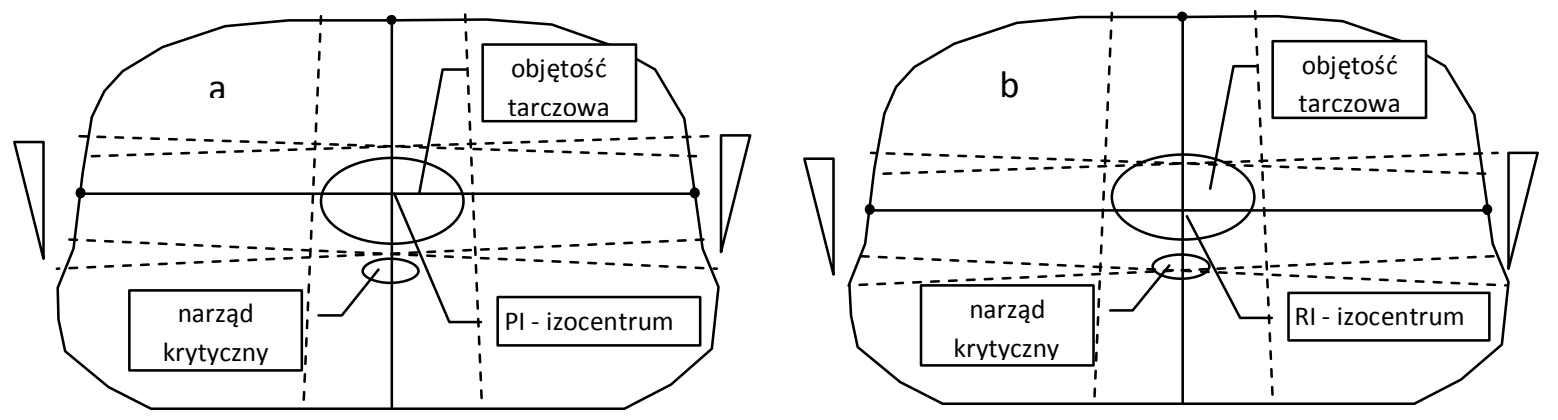

Rycina 1.1. Geometria napromieniania pacjenta $z$ nowotworem gruczołu krokowego. Wskutek napięcia mięśni znaczniki boczne przemieściły się ku dołowi, co spowodowało błąd geometryczny. PI - zaplanowane izocentrum, RI - realizowane izocentrum.

\section{Jak określać błędy ułożenia pacjentów?}

Ilościowo błąd ułożenia pacjenta jest określany poprzez wyznaczenie w czasie napromieniania położenia układu wiązek w układzie pacjenta. W idealnej sytuacji, gdy pacjent jest ułożony prawidłowo, położenie wiązek wyznaczone w układzie pacjenta powinno być takie samo jak określone w planie leczenia. Zdefiniujmy układ współrzędnych wiązki terapeutycznej oraz układ współrzędnych pacjenta. Początek układu wiązki terapeutycznej jest umieszczany na osi centralnej wiązki w punkcie znajdującym się w odległości izocentrycznej od źródła promieniowania (izocentrum aparatu). Jedna $\mathrm{z}$ osi znajduje się $\mathrm{w}$ osi centralnej wiązki a dwie pozostałe w płaszczyznach centralnych. Układ współrzędnych pacjenta jest zwykle definiowany w odniesieniu do struktur kostnych znajdujących się blisko objętości tarczowej. W sytuacji najkorzystniejszej, z punktu widzenia bezpieczeństwa prowadzenia terapii, objętość tarczowa nie zmienia swojego położenia względem struktur kostnych określających układ współrzędnych pacjenta. Z taką sytuacją spotykamy się np. w przypadku napromieniania pacjentów w rejonie mózgu. Kości czaszki można uznać za nieruchome względem mózgu. Niestety w większości przypadków żadnej ze struktur kostnych nie można uznać za nieruchomą względem objętości tarczowej, co zmniejsza wiarygodność kontroli ułożenia realizowanej poprzez porównanie położenia układu wiązki względem układu pacjenta w czasie napromieniania i układu pacjenta określonego w planie leczenia. Tym niemniej ze względu na brak szerokiej dostępności bardziej wiarygodnych metod określania zgodności realizowanego i zaplanowanego planu leczenia, w większości przypadków, kontrola ułożenia jest prowadzona $\mathrm{z}$ zastosowaniem struktur kostnych. Dlatego w każdej konkretnej sytuacji klinicznej należy określić układ współrzędnych pacjenta poprzez wskazanie odpowiednich struktur kostnych. Na przykład w rejonie miednicy początek tego układu można umieścić w szczycie spojenia łonowego a osie skierować w taki sposób, aby jedna $\mathrm{z}$ osi była równoległa do osi długiej kręgosłupa, dwie pozostałe prostopadłe do niego. Ze względu jednak na to, że kontrola ułożenia pacjenta jest $\mathrm{w}$ ogromnej większości realizowana poprzez porównanie płaskich zdjęć pola terapeutycznego $\mathrm{z}$ odpowiednimi obrazami pól terapeutycznych uzyskanymi w czasie planowania leczenia drogą cyfrowej rekonstrukcji, w celu określenia wzajemnego położenia układu współrzędnych pacjenta postępujemy mniej formalnie a bardziej praktycznie. Umownie, układ współrzędnych pacjenta określają najlepiej uwidocznione struktury kostne oraz granice pola terapeutycznego. Właściwy wybór struktur anatomicznych jest istotnym elementem kontroli ułożenia pacjenta. Będzie o tym mowa w III części zaleceń (PJMPE 2015;21(1):27-31).

$\mathrm{W}$ prawidłowo zrealizowanym pod względem geometrycznym napromienianiu wzajemne położenie granic pola i struktur anatomicznych zarejestrowane na zdjęciu portalowym jest takie samo jak na obrazie odniesienia! Należy podkreślić, że obrazy odniesienia, czyli te, z którymi porównywane są obrazy portalowe powinny być tworzone podczas planowania leczenia. Oznacza to, że jeżeli plan leczenia jest przygotowywany z użyciem systemu planowania leczenia, w którym informację obrazową stanowią obrazy tomograficzne, obrazami odniesienia muszą być obrazy zrekonstruowane na podstawie obrazów tomografii komputerowej. Natomiast, w wyjątkowym przypadku, jeżeli plan leczenia jest przygotowywany wyłącznie z użyciem konwencjonalnego symulatora terapeutycznego, to obrazami odniesienia powinny być obrazy uzyskane w trakcie symulacji. Rekonstrukcje radiograficzne pól terapeutycznych oraz obrazy $\mathrm{z}$ symulatora będą $\mathrm{w}$ dalszej części określane jako obraz odniesienia $-\mathrm{z}$ nimi będą porównywane zdjęcia wykonane $\mathrm{w}$ czasie terapii. Porównanie obrazu odniesienia i zdjęcia wykonanego $\mathrm{w}$ czasie terapii polega zwykle na nałożeniu widocznych na obydwu zdjęciach tych samych struktur anatomicznych (zwykle kostnych) i określeniu wektora o jaki należy przesunąć pole zarejestrowane na zdjęciu terapeutycznym, aby pokryły się granice pól terapeutycznego i zaplanowanego. W wielu przypadkach $\mathrm{w}$ celu nałożenia struktur anatomicznych na siebie, niezbędne jest również wykonanie obrotu płaszczyzny względem osi centralnej jednego obrazu tak, aby precyzyjnie nałożyć obraz odniesienia i obraz pola terapeutycznego. Porównanie obrazu pola zarejestrowanego $\mathrm{w}$ czasie napromieniania i rekonstrukcji radiograficznej pozwala określić trzy wartości: dwie współrzędne określające wektor translacji oraz kąt, o jaki należy obrócić jedno pole względem drugiego. 

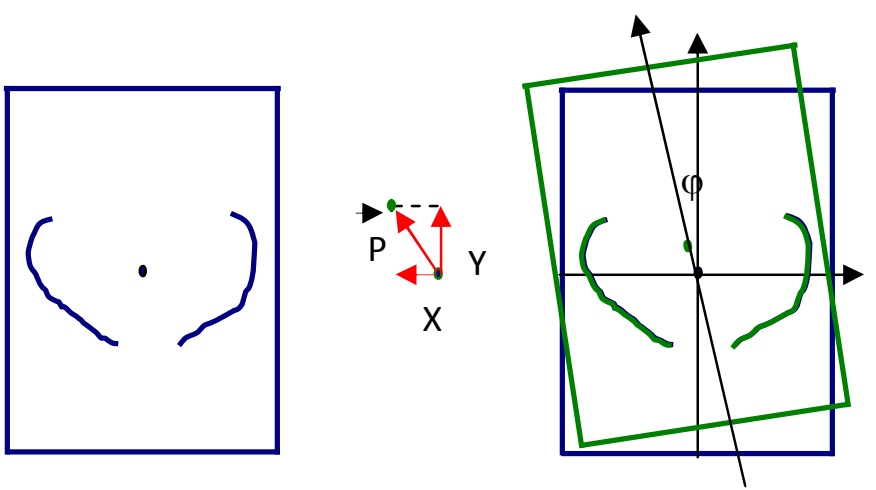

Rycina 2.1. Obraz odniesienia (rekonstrukcja radiograficzna) $z$ zaznaczonymi konturami miednicy (strona lewa). Obraz odniesienia nałożony na zdjęcie portalowe $z$ zaznaczonymi konturami miednicy (strona prawa). Wyznaczono wektor i kąt obrotu pozwalające na nalożenie konturów miednicy. (Dzięki życzliwości dr. Andrzeja Dąbrowskiego)

Na rycinie 2.1 pokazano schematycznie obraz pola zaplanowanego oraz zdjęcie wykonane $\mathrm{w}$ czasie napromieniania $\mathrm{z}$ zaznaczonymi konturami miednicy.

Po nałożeniu widocznych struktur miednicy na siebie otrzymywana jest liczbowa informacja określająca niezgodność ułożenia pacjenta. W sytuacji pokazanej na rycinie 2.1 należało pole terapeutyczne obrócić o kąt $\varphi$ i przesunąć o wektor $\vec{P}(x, y)$.

$\mathrm{W}$ opisanym schemacie postępowania, najczęstszym w praktyce klinicznej, kontrola ułożenia jest przeprowadzana $\mathrm{z}$ użyciem płaskich obrazów. Takie porównanie pozwala na porównanie pozycji pola terapeutycznego względem pola zaplanowanego tylko w dwóch kierunkach i pozwala na określenie rotacji tylko wokół jednej osi. Jeżeli wykonane zostanie dodatkowo zdjęcie prostopadłe do tego pierwszego pola, to uzyskana zostanie informacja o trzeciej współrzędnej i informacja o rotacji względem drugiej osi.

Postępowanie, w którym plan leczenia jest przygotowywany z użyciem systemu planowania leczenia, natomiast obrazy odniesienia powstają na symulatorze terapeutycznym, może być obarczone dodatkowym błędem. Układanie pacjenta na symulatorze zawsze wnosi pewne niedokładności, które prowadzą do uzyskaniem błędnego obrazu odniesienia. Następstwem takiego postępowania jest każdorazowe odnoszenie zdjęć portalowych podczas weryfikacji do nieprawidłowych obrazów odniesienia. Ta sytuacja jest określana angielskim terminem "transfer error".

W nowoczesnych systemach kontroli ułożenia metodami tomografii komputerowej uzyskiwany jest trójwymiarowy obraz ciała pacjenta $w$ czasie realizacji terapii. Taki trójwymiarowy obraz ciała pacjenta jest porównywany $\mathrm{z}$ analogicznym trójwymiarowym obrazem ciała pacjenta uzyskanym do planowania leczenia. Użycie do kontroli ułożenia pacjenta obrazów trójwymiarowych pozwala na określenie w jednym porównaniu trzech współrzędnych wektora translacji i trzech kątów obrotu wokół trzech prostopadłych osi. Należy mieć świadomość, że przedstawione zasady wyznaczania wzajemnego położenia układów wiązki i układu pacjenta określone na etapie planowania leczenia i realizacji leczenia mogłyby być ściśle zrealizowane, gdyby pacjent mógł być traktowany jak bryła sztywna. W rzeczywistości zmiany kształtu ciała pacjenta (np. skręcenie tułowia) i struktur anatomicznych (np. inne wygięcie szyi powodujące zmianę kształtu kręgosłupa) znacząco utrudniają proces kontroli ułożenia. Dlatego w większości rzeczywistych sytuacji klinicznych jednoznaczne nałożenie struktur kostnych na siebie nie jest możliwe. W takim przypadku osoba przeprowadzająca kontrolę jest zmuszona do podjęcia arbitralnej decyzji określającej wektor przesunięcia i kąt obrotu. Jeżeli osoba przeprowadzająca kontrolę zaobserwuje znaczną zmianę kształtu ciała pacjenta powinna rozważyć ponowne ułożenie pacjenta $\mathrm{w}$ pozycji terapeutycznej i rozpocząć kontrolę od początku.

\section{Analiza ilościowa błędów ułożenia}

\section{1 Błędy systematyczne i przypadkowe}

Popełniane błędy w realizacji leczenia są opisywane za pomocą języka analizy błędów pomiarowych. Szczególną rolę w analizie błędów odgrywają pojęcia błędów systematycznych i przypadkowych.

Błędy systematyczne to rodzaj błędów, które powodują, że w sposób stały, w trakcie kolejnych sesji napromieniania, izocentrum wiązek realizowanych jest przesunięte w tym samym kierunku, o podobną wartość, względem izocentrum zaplanowanego. Aby wyjaśnić pojęcie błędów systematycznych i przypadkowych rozważmy następująca sytuację, przygotowania do zawodów strzeleckich. Umiejętności strzelca są wysokie. Zwykle wszystkie strzały trafiały co najmniej w ósemkę. Strzelec otrzymuje nową, podobno świetną broń. $\mathrm{Na}$ strzelnicy wypróbowuje jej możliwości. Oddaje dziesięć strzałów i otrzymuje wyniki, jak na rycinie 3.1.

W przypadku A wszystkie trafienia skupiły się na prawo i powyżej od centrum. Wniosek jest prosty. Aparat celowniczy jest błędnie ustawiony. Powoduje, że pociski są systematycznie „znoszone” na prawo, w górę. Po dokonaniu odpowiednich korekt w ustawieniu lunety celowniczej uzyskuje wynik, którego oczekiwał. Trafienia są skupione wokół centrum tarczy (B). W obydwu przypadkach strzały są skupione dość blisko siebie. Oznacza to, że popełniany jest niewielki błąd systematyczny. W sytuacji przedstawionej na rysunku $\mathrm{C}$ trafienia są znacznie oddalone od środka tarczy i dość daleko oddalone od siebie. Oznacza to, że popełniany jest zarówno duży błąd systematyczny, jak i przypadkowy. Natomiast na rysunku D mimo, iż trafienia są dość daleko oddalone od siebie, to jednak średnio koncentrują się wokół środka tarczy. Popełniany jest duży błąd przypadkowy.

Napromienianie jest takim strzelectwem gdzie tarczą jest zmiana nowotworowa. $Z$ jakichś powodów może się okazać, że $\mathrm{np}$. izocentrum jest systematycznie przesunięte $\mathrm{w}$ kierunku głowy pacjenta. 

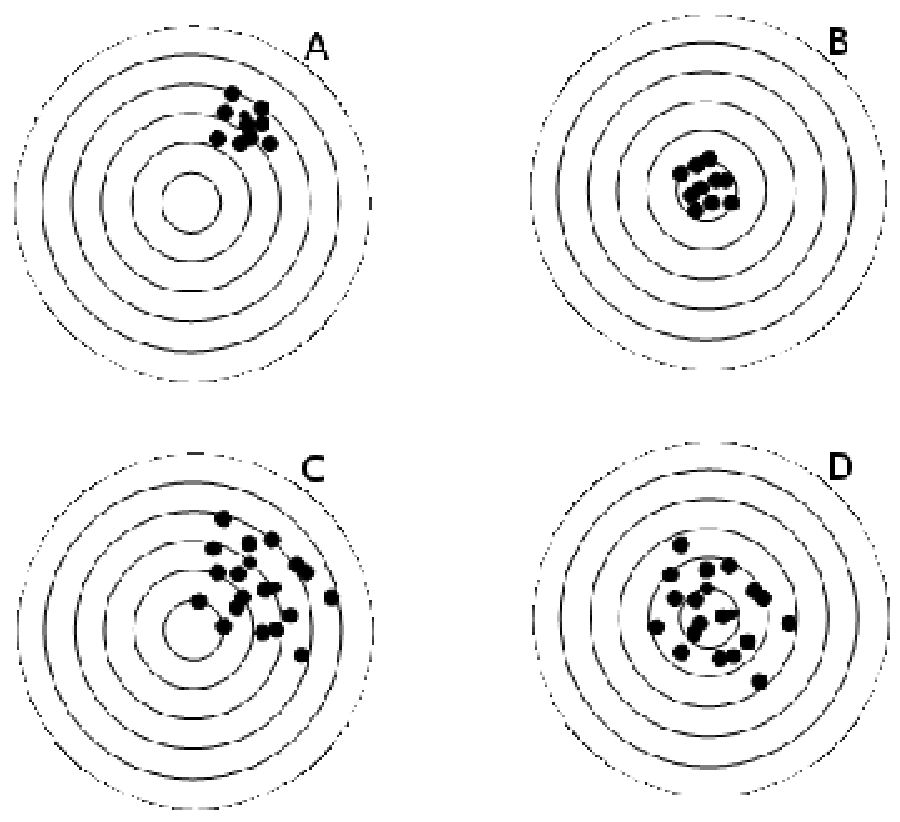

Rycina 3.1. Rozkład strzałów uzyskany dla nowej broni. Schematyczna prezentacja błędów systematycznych i przypadkowych. A - mały błąd systematyczny, duży błąd przypadkowy; B - mały błąd systematyczny i przypadkowy; C duży błąd systematyczny i przypadkowy; D - mały błąd systematyczny, duży błąd przypadkowy.

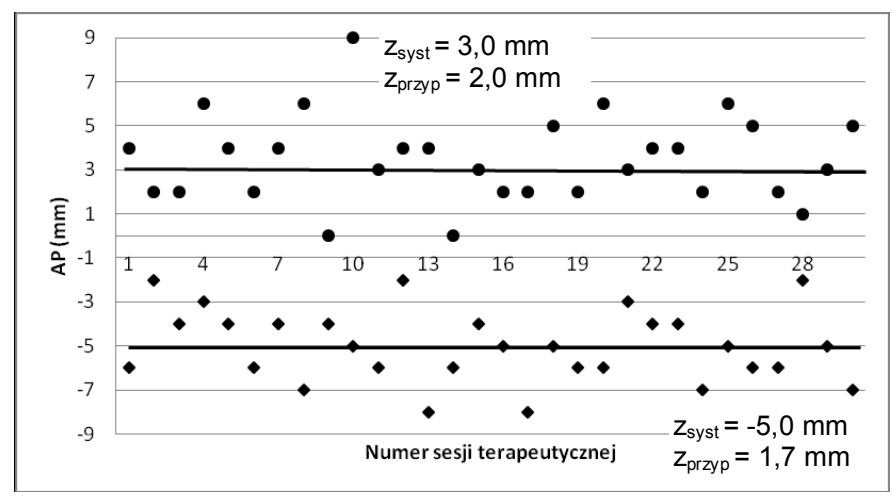

Rycina 3.2. Wyniki kontroli ułożenia dwóch pacjentów (koła pacjent A, romby - pacjent B) w kierunku AP. Kontrolę wykonano w każdej $z \quad 30$ sesji terapeutycznych. Bląd systematyczny dla pacjenta A wyniósł $3,0 \mathrm{~mm}$, błąd przypadkowy 2,0 mm. Błąd systematyczny dla pacjenta $B$ wyniósł $-\mathbf{5 , 0} \mathrm{mm}$, błąd przypadkowy $1,7 \mathrm{~mm}$. Linią pogrubioną zaznaczono wartości błędów systematycznych.

Sama wiedza o tym, że popełniany jest błąd systematyczny jest ważna, ale niewystarczająca. Chcielibyśmy również wiedzieć jak duży jest błąd systematyczny. Jak zatem wyrazić błąd systematyczny? Miarą błędu systematycznego jest wartość średnia wektora przesunięcia położenia izocentrum realizowanego względem izocentrum zaplanowanego. $\mathrm{Na}$ rycinie 3.2 pokazano wyniki pomiaru położenia izocentrum $\mathrm{w}$ kierunku góra-dół dla dwóch pacjentów leczonych w powodu nowotworu gruczołu krokowego wyznaczone na podstawie kontroli portalowej.
Dla pacjentów A i B, ułożonych na plecach uzyskano wartość średnią przesunięcia pozycji izocentrum w kierunku przód-tył odpowiednio o wartość 3,0 i -5,0 mm (przyjęto, że wartości dodatnie uzyskiwane są w sytuacji, gdy izocentrum jest przesunięte do góry względem izocentrum zaplanowanego). Liczbowo wartość średnią przesunięcia izocentrum realizowanego względem zaplanowanego w kierunku przód-tył można obliczyć ze wzoru:

$z_{\text {syst }}=\frac{\sum_{i=1}^{K} z_{i}}{K}$

Wzór 3.1

gdzie $z_{i}$ - przesunięcie izocentrum $w$ i-tej sesji terapeutycznej względem izocentrum zaplanowanego, K - liczba sesji terapeutycznych, w których wykonano kontrolę portalową i określono położenie izocentrum.

Błąd przypadkowy to różnica pomiędzy położeniem izocentrum uzyskanym w danej sesji terapeutycznej i średniej wartości położenia izocentrum. Miarą błędu przypadkowego jest odchylenie standardowe, które obliczyć można ze wzoru:

$z_{\text {przyp }}=\sigma_{z}=\sqrt{\frac{\sum_{i=1}^{K}\left(z_{i}-z_{\text {syst }}\right)^{2}}{K-1}}$

Wzór 3.2

We wzorze 3.2 użyto tych samych oznaczeń jak we wzorze 3.1. Grecką literkę $\sigma$ wprowadzono, gdyż w literaturze fachowej tak właśnie oznaczany jest błąd przypadkowy. $\mathrm{Na}$ rycinie 3.2 dla każdego pacjenta obok wartości błędu systematycznego umieszczono wartość błędu przypadkowego.

Kompletną informację na temat błędu systematycznego i przypadkowego uzyskujemy dla pojedynczego pacjenta dopiero po zakończeniu leczenia, jeżeli w każdej sesji terapeutycznej wykonaliśmy kontrolę ułożenia. Taka wiedza jest interesująca, ale niestety nie pozwala zapewnić właściwego leczenia pacjentowi, dla którego zgromadzono wyniki kontroli portalowej. Celem kontroli portalowej jest nie tyle określenie wartości tych błędów, co spowodowanie, żeby pacjent był napromieniany zgodnie z planem leczenia. Realizacji tego celu służą metody korekcji ułożenia pacjenta. W tym celu niezbędne jest wyznaczenie nie tylko błędów systematycznych u pojedynczych pacjentów, ale również znajomości rozkładów tych błędów w grupach ,podobnych” pacjentów. Taką grupę pacjentów będziemy określać, jako jednorodną grupę pacjentów - JGP. Przez JGP rozumieć będziemy pacjentów leczonych z powodu tej samej choroby nowotworowej, tą samą techniką napromieniania, u których nie stwierdza się jakichś szczególnych anomalii. Na przykład pacjent wyjątkowo otyły nie powinien zostać zaliczony do takiej grupy. Rozkłady błędów w JGP określają wartości błędów systematycznych i przypadkowych w grupie, inaczej określane jako wartości populacyjne błędów ułożenia.

Załóżmy, że jednorodna grupa pacjentów składa się z N pacjentów. Dla każdego pacjenta wyznaczono wartość błędu systematycznego. Jako miarę błędu systematycznego w JGP 
przyjęto odchylenie standardowe obliczone po zbiorze wartości błędów systematycznych. A zatem tak jak dla pojedynczego pacjenta najpierw należy policzyć wartość średnią po błędach systematycznych (błędy systematyczne w grupie są oznaczane dużymi literami).

$Z_{s r}=\frac{\sum_{j=1}^{N}\left(z_{s y s t}\right)_{j}}{N}$

Wzór 3.3

Błąd systematyczny w grupie jest dany wzorem:

$Z_{\text {syst }}=\Sigma=\sqrt{\frac{\sum_{j=1}^{N}\left(\left(z_{s y s t}\right)_{j}-Z_{s r}\right)^{2}}{N-1}}$

Wzór 3.4

Podobnie wyznaczany jest błąd przypadkowy dla grupy pacjentów. W tym przypadku miarą błędu systematycznego jest wartość średnia obliczona po zbiorze błędów przypadkowych.

$$
Z_{\text {przyp }}=\frac{\sum_{j=1}^{N}\left(z_{p r z y p}\right)_{j}}{N}
$$

Wzór 3.5

Rozważania przeprowadzono jedynie dla kierunku z. Identycznie należy postąpić dla dwóch pozostałych kierunków x, y. W tabeli 3.1 pokazano wyniki kontroli ułożenia dla jednorodnej grupy 8 pacjentów wyznaczone dla kierunku AP. Obliczono błąd systematyczny i przypadkowy dla każdego pacjenta oraz błąd systematyczny i przypadkowy dla jednorodnej grupy pacjentów.

Uzyskane dane pozwalają ustalić, że wartość błędu systematycznego w jednorodnej grupie wynosi 2,7 mm (wzór 3.4) i wartość błędu przypadkowego w jednorodnej grupie wynosi 1,7 mm (wzór 3.5).

Tabela 3.1. Wyniki kontroli ułożenia 8 pacjentów chorych na ten sam nowotwór leczonych taką samą techniką. Kontrole ulożenia były wykonywane dwa razy $w$ tygodniu, w poniedzialek $i$ czwartek. Wszystkie wyniki podano w milimetrach.

\begin{tabular}{lcccccccc}
\hline \hline $\begin{array}{l}\text { Numer } \\
\text { pacjenta }\end{array}$ & $\mathbf{1}$ & $\mathbf{2}$ & $\mathbf{3}$ & $\mathbf{4}$ & $\mathbf{5}$ & $\mathbf{6}$ & $\mathbf{7}$ & $\mathbf{8}$ \\
\hline Poniedziałek & 4 & -2 & 3 & 2 & -5 & 1 & -4 & 2 \\
Czwartek & 1 & -3 & 4 & -1 & -4 & 3 & -5 & 2 \\
Poniedziałek & 2 & -1 & 4 & 4 & -1 & 2 & -4 & 3 \\
Czwartek & 5 & -1 & 2 & -3 & -3 & -1 & -3 & 4 \\
Poniedziałek & 3 & -2 & 2 & -2 & -5 & 4 & -2 & 2 \\
Czwartek & 4 & -3 & 2 & -1 & -3 & 2 & -5 & 3 \\
Poniedziałek & 6 & 2 & -2 & 0 & -2 & 3 & -4 & 5 \\
Czwartek & 0 & -2 & 0 & 2 & -3 & 4 & -4 & 2 \\
Poniedziałek & 4 & -2 & -1 & -1 & -3 & -1 & -2 & 3 \\
Czwartek & 4 & -2 & -1 & -3 & -4 & -1 & -4 & 5 \\
\hline $\mathbf{z}_{\text {syst }}$ & $\mathbf{3 , 3}$ & $\mathbf{- 1 , 6}$ & $\mathbf{1 , 3}$ & $\mathbf{- 0 , 3}$ & $\mathbf{- 3 , 3}$ & $\mathbf{1 , 6}$ & $\mathbf{- 3 , 7}$ & $\mathbf{3 , 1}$ \\
\hline $\mathbf{z}_{\mathbf{p r z y p}}$ & $\mathbf{1 , 8}$ & $\mathbf{1 , 4}$ & $\mathbf{2 , 2}$ & $\mathbf{2 , 3}$ & $\mathbf{1 , 3}$ & $\mathbf{2 , 0}$ & $\mathbf{1 , 1}$ & $\mathbf{1 , 2}$ \\
\hline \hline
\end{tabular}

Natomiast wartość średniej policzonej po średnich dla pojedynczych pacjentów (wzór 3.3) wynosi $0,05 \mathrm{~mm}$. Jest ona nieznamiennie różna od zera $(\mathrm{p}>0,05)$. Oznacza to, że nie ma podstaw, aby twierdzić iż w całym procesie przygotowania i leczenia pacjentów tej grupy popełniany jest błąd systematyczny. To bardzo ważny wniosek. Gdyby wartość średnia była różna od zera należałoby przeanalizować wszystkie kroki przygotowania i realizacji leczenia celem znalezienia przyczyny uzyskania takiego wyniku.

Mówiąc o błędach ułożenia pacjenta pominięto zagadnienie rotacji. Wyniki określające rotację można ilościowo analizować w podobny sposób jak wyniki określające translację. Analiza danych klinicznych wskazuje, że zwykle rotacje pól są stosunkowo niewielkie i dlatego zwykle są pomijane. Dodatkowo dość trudno jest przeciwdziałać zaobserwowanym rotacjom. W przypadku stwierdzenia rotacji pacjenta jedyne racjonalne działanie polega na zwróceniu szczególnej uwagi na sposób układania pacjenta oraz ewentualnie na zmianie zastosowanych podpórek stabilizujących.

\subsection{Interpretacja błędów systematycznych i przypadkowych}

Interpretacja błędów dla pojedynczego pacjenta jest dość prosta. Błąd systematyczny mówi o średniej różnicy położenia izocentrum realizowanego względem izocentrum zaplanowanego. Błąd przypadkowy jest natomiast miarą zmienności położenia izocentrum realizowanego względem jego średniego położenia w trakcie trwania terapii.

Miary błędów określone dla grup pacjentów wymagają bardziej szczegółowego omówienia. Znajomość wartości błędów określonych dla jednorodnej grupy pacjentów pozwala ocenić jakość terapii i podjąć stosowne działania w celu zminimalizowania błędów ułożenia, oraz jest wykorzystywana do określenia marginesu wokół Klinicznego Obszaru do Napromieniania. Wartość średnia przesunięcia izocentrum realizowanego względem izocentrum zaplanowanego $\left(\mathrm{X}_{\mathrm{sr}}, \mathrm{Y}_{\mathrm{sr}}, \mathrm{Z}_{\mathrm{sr}}\right)$, obliczona dla jednorodnej grupy pacjentów (wzór 3.3) powinna być bliska zeru. Jeżeli tak nie jest (odpowiedź, czy ta wartość różni się od zera można uzyskać metodami statystycznymi - test Studenta), to oznacza, że najprawdopodobniej istnieje tzw. „transfer error”, czyli jakaś niespójność pomiędzy układami zewnętrznymi (zwykle układami wyznaczonymi przez centratory laserowe) zainstalowanymi w pomieszczeniu terapeutycznym i w pomieszczeniach, w których pacjenci są przygotowywani do leczenia, np. na tomografie komputerowym. Innym typowym źródłem istnienia takiego znamiennego statystycznie błędu systematycznego jest ugięcie stołu, lub też różnica $\mathrm{w}$ stosowanych urządzeniach stabilizujących. Jeżeli np. na tomografie stół diagnostyczny jest płaskim, bardzo sztywnym stołem $\mathrm{z}$ włókna węglowego a na akceleratorze stół jest stołem z wkładką mylarową, która znacząco ugina się pod wpływem ciężaru ciała pacjenta, można się spodziewać systematycznych 
różnic w ułożeniu pacjentów na tych dwóch urządzeniach. Podobnie źródłem błędów systematycznych mogą być różnice pomiędzy unieruchomieniami używanymi na tomografie komputerowym i urządzeniu terapeutycznym. Po stwierdzeniu, że istnieje ,transfer error" należy niezwłocznie podjąć działania, aby zidentyfikować źródło tego błędu i wyeliminować go.

Inną ważną informację dostarcza wartość populacyjnego błędu systematycznego obliczona ze wzoru 3.4 - odchylenie standardowe po wartościach średnich. W oparciu o cechy rozkładu normalnego można podać następującą interpretację uzyskanej wartości błędu systematycznego w grupie. Izocentrum realizowane, średnio w czasie całego leczenia, będzie przesunięte względem punktu o współrzędnych $\left(\mathrm{X}_{\text {sr }}, \mathrm{Y}_{\text {sr }}, \mathrm{Z}_{\text {sr }}\right)$ o wektor większy niż $\left( \pm 2 \mathrm{X}_{\text {syst }}, \pm 2 \mathrm{Y}_{\text {syst }}, \pm 2 \mathrm{Z}_{\text {syst }}\right) \mathrm{u}$ około 5\% pacjentów. Oczywiście na ten średni błąd systematyczny dodatkowo w trakcie leczenia nakładać się będzie błąd przypadkowy. Położenie izocentrum będzie średnio w grupie pacjentów, w kolejnych sesjach terapeutycznych, fluktuowało wokół położenia wyznaczonego przez wartość średnią, a częstość występowania tych fluktuacji określa dla każdego kierunku rozkład normalny o cechach $\left(\mathrm{X}_{\text {przyp }}, \mathrm{Y}_{\text {przyp }}, \mathrm{Z}_{\text {przyp }}\right)$.

Bardzo często jako główny cel kontroli ułożenia przyjmuje się wykrycie na jak najwcześniejszym etapie leczenia popełnienie błędu systematycznego. W przypadku stwierdzenia istnienia tego błędu niezbędne jest skorygowanie ułożenia pacjenta. Odpowiedź na takie pytanie w kategoriach ilościowych wymaga zweryfikowania hipotezy, czy wartość średnia położenia izocentrum realizowanego różni się znamiennie statystycznie od położenia izocentrum zaplanowanego. Możliwość uzyskania odpowiedzi na to pytanie zależy w dużym stopniu od wielkości błędu przypadkowego, określonego dla jednorodnej grupy pacjentów. W przypadku, gdy błąd przypadkowy określony dla grupy pacjentów (wzór 3.5) jest duży w stosunku do błędu systematycznego (wzór 3.4) bardzo trudno uzyskać wiarygodną odpowiedź na to pytanie, gdyż błędy przypadkowe maskują błędy systematyczne. Dlatego, aczkolwiek to właśnie błędy systematyczne należy uznać za najniebezpieczniejsze dla wyniku napromieniania, to jednak wydanie wiążącego sądu o nich jest zależne od tego, czy leczenie jest powtarzalne, czy nie. Głównym źródłami słabej powtarzalności napromieniania są: słaba współpraca pacjenta z zespołem realizującym leczenie oraz brak dokładności osób układających pacjentów w czasie przygotowania do napromieniania.

\section{Metody korekcji ułożenia}

Metody korekcji dzielą się na metody korekcji on- i off-line. W pierwszym przypadku, w metodach on-line, przed podaniem pełnej dawki terapeutycznej uzyskiwana jest ilościowa informacja o prawidłowości ułożenia pacjenta i następnie dokonywana jest stosowna korekta ułożenia pacjenta. W metodach off-line w trakcie sesji terapeutycznej wykonywana jest kontrola ułożenia bez jakiejkolwiek zmiany pozycji pacjenta. Uzyskany wynik z kontroli ułożenia jest wykorzystywany do korekcji ułożenia pacjenta w następnej lub $\mathrm{w}$ jednej $\mathrm{z}$ następnych sesji terapeutycznych. Zasadnicza różnica pomiędzy tymi dwoma rodzajami kontroli polega na tym, że tylko korekcja on-line pozwala na zmniejszenie zarówno błędów systematycznych jak i przypadkowych, podczas gdy w schematach off-line możliwe jest jedynie zmniejszenie błędów systematycznych. Wydaje się zatem, że metoda on-line ma znaczącą przewagę nad schematami offline. Jednakże ta metoda wiąże się $z$ dużym nakładem pracy $i$ znaczącym wydłużeniem sesji terapeutycznej, co może (paradoksalnie!) wpłynąć na prawidłowość ułożenia pacjenta. Takie postępowanie może również prowadzić do osłabienia czujności zespołu układającego pacjenta. Samo wykonanie zdjęcia portalowego lub tomografii na urządzeniu terapeutycznym nie zajmuje specjalnie dużo czasu. Jednakże, w wielu przypadkach, dość dużo czasu zajmuje uzyskanie ilościowej informacji o wektorze przesunięcia i podjęcie właściwej decyzji. Można również połączyć te dwa schematy postępowania, off-line i on-line.

\subsection{Metoda No Action Level (NAL)}

Jak zaznaczono powyżej błędy systematyczne mają największy wpływ na wynik leczenia. Dlatego wszystkie metody korekcji ułożenia skupiają się na zmniejszeniu błędu systematycznego. Najprostszą jest metoda, w której sposób postępowania jest następujący. W kilku pierwszych frakcjach wykonywana jest kontrola ułożenia i uzyskiwana jest ilościowa informacja o przesunięciu izocentrum realizowanego względem zaplanowanego. Następnie obliczana jest wartość średnia wektora przesunięcia $\mathrm{i}$ w następnych frakcjach po ułożeniu pacjenta stół terapeutyczny jest przesuwany o wektor niwelujący błąd systematyczny. Obliczona wartość średnia jest estymatą błędu systematycznego u pojedynczego pacjenta. Ten schemat postępowania został zaproponowany przez grupę $\mathrm{Z}$ Rotterdamu i jest określany angielską nazwą „No Action Level - NAL". W tym schemacie postępowania kontrole są zwykle ułożenia są wykonywane $\mathrm{w}$ pierwszych trzech sesjach terapeutycznych - wartość średnia jest liczona z trzech wartości. Na rycinie 4.1 pokazano wyniki kontroli ułożenia pacjenta w kierunku góra-dół wykonane w każdej z 30 frakcji.

Wartość średnia różnicy położenia izocentrum realizowanego i zaplanowanego, wyznaczona na podstawie kontroli ułożenia wykonanej we wszystkich sesjach terapeutycznych, w kierunku AP wynosi $-5 \mathrm{~mm}$. Średnio izocentrum realizowane znajdowało się powyżej izocentrum zaplanowanego. Wartość wektora przesunięcia wyznaczona na podstawie pomiarów wykonanych w pierwszych trzech frakcjach wyniosła $-4 \mathrm{~mm}$. Dlatego, postępując zgodnie $\mathrm{z}$ metodą NAL od czwartej sesji terapeutycznej po ułożeniu pacjenta na stole terapeutycznym $\mathrm{w}$ taki sam sposób, jak wykonywano to w czasie pierwszych trzech sesji terapeutycznych, przesuwano stół terapeutyczny o $4 \mathrm{~mm}$ do 
góry. Na rycinie 4.1 nie zamalowane romby określają różnicę pomiędzy izocentrum realizowanym i zaplanowanym po dokonanej korekcie. Wartość średnia różnicy położenia izocentrów dla 30 frakcji bez korekty wynosi $-5,0 \mathrm{~mm}$ a $\mathrm{z}$ korektą -1,0 mm (skorygowano położenie pacjenta o estymowaną na podstawie pierwszych 3 frakcji wartość błędu systematycznego, czyli $4 \mathrm{~mm}$, zamiast o $5 \mathrm{~mm}$, które można było obliczyć dopiero po zrealizowaniu wszystkich 30 frakcji). Dzięki dokonanej korekcie uzyskano znaczącą poprawę jakości leczenia. Warto zauważyć, że błąd przypadkowy nie zmienił się, rozrzut położenia izocentrum realizowanego wokół średniego położenia izocentrum pozostał taki sam.

\subsection{Metoda Shrinking Action Level (SAL)}

Drugim schematem, który warto omówić jest schemat „Shrinking Action Level - SAL”. Propozycja tego sposobu postępowania wyszła z Amsterdamu. Zasadniczym celem tego schematu postępowania jest jak najszybsze uzyskanie odpowiedzi na pytanie, czy popełniono błąd systematyczny a ściślej, czy ułożenie pacjenta nie odbiega od zaplanowanego o więcej niż ustalona z góry wartość, określana terminem ,„próg reagowania”. Wartość progu reagowania jest ustalana zanim pacjent rozpocznie leczenie. Drugim parametrem metody, który należy ustalić przed rozpoczęciem napromieniania jest liczba sesji terapeutycznych, po których kończona jest kontrola ułożenia pacjenta, jeżeli żaden $\mathrm{z}$ wyników nie przekroczył progu reagowania. Należy zaznaczyć, że w kolejnych sesjach terapeutycznych wartość progu reagowania maleje. Wartość zmniejszonego progu reagowania jest wyznaczana poprzez podzielenie pierwotnej wartości progu reagowania przez pierwiastek kwadratowy z liczby sesji, w których wykonano kontrolę, bez korekty ułożenia pacjenta. Autorzy tego schematu postępowania pokazali metodami Monte Carlo, że dobrą wartością początkowego progu reagowania jest podwojona wartość błędu przypadkowego określonego dla jednorodnej grupy pacjentów, czyli np. dla osi $\mathrm{X}$ wartość $2 \cdot \mathrm{X}_{\text {przyp }}$, a liczba kontroli, po której podejmowana jest wiążąca decyzja to 2 . Używając wyników przedstawionych w tabeli 3.1 początkowa wartość progu reagowania wyniosłaby najprawdopodobniej $4 \mathrm{~mm}$ (zaokrąglenie w górę błędu przypadkowego 3,4 $\mathrm{mm}$ ). Takie dane wejściowe umożliwiają z bardzo dużym prawdopodobieństwem wykrycie istnienia błędu systematycznego przekraczającego poziom reagowania. Wyjaśnijmy bardziej szczegółowo jak w praktyce wykonywana jest kontrola zgodnie ze schematem zmniejszającego się poziomu reagowania i dlaczego „zmniejszającego się”? Po wykonaniu pierwszej kontroli uzyskany wynik jest porównywany z poziomem reagowania $\mathrm{i}$ jeżeli realizowane izocentrum jest przesunięte względem zaplanowanego o większą wartość niż początkowy poziom reagowania to przed podaniem kolejnej frakcji podejmowana jest próba znalezienia przyczyny stwierdzonej różnicy.

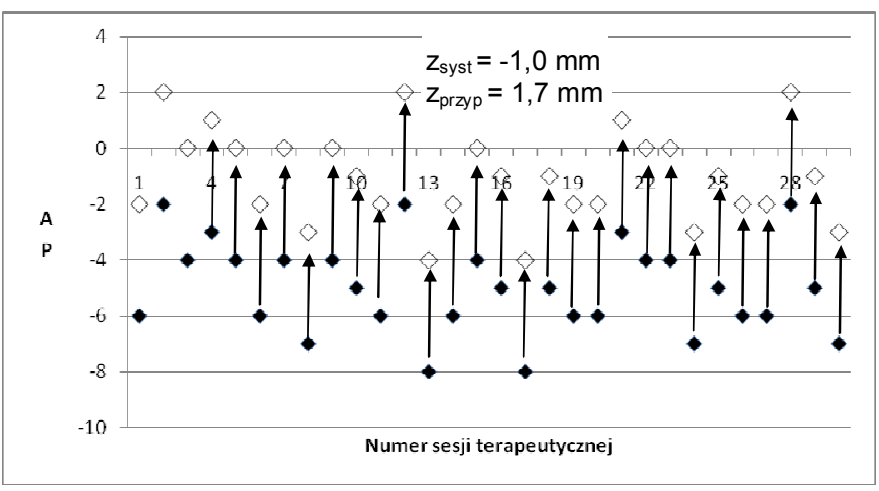

Rycina 4.1. Schemat NAL. Różnica pomiędzy ułożeniem pacjenta w czasie napromieniania i zaplanowanym w kierunku AP (romby nie wypelnione) po dokonaniu korekcji o wartość równą błędowi systematycznemu wyznaczonemu na podstawie pomiarów dokonanych w pierwszych trzech frakcjach. Symbolicznie korektę zaznaczono czarnymi strzałkami. Należy zauważyć, że po takiej korekcie błąd systematyczny wynosi tylko $-1,0 \mathrm{~mm}$, natomiast błąd przypadkowy nie uległ zmianie. Nadal wynosi $1,7 \mathrm{~mm}$.

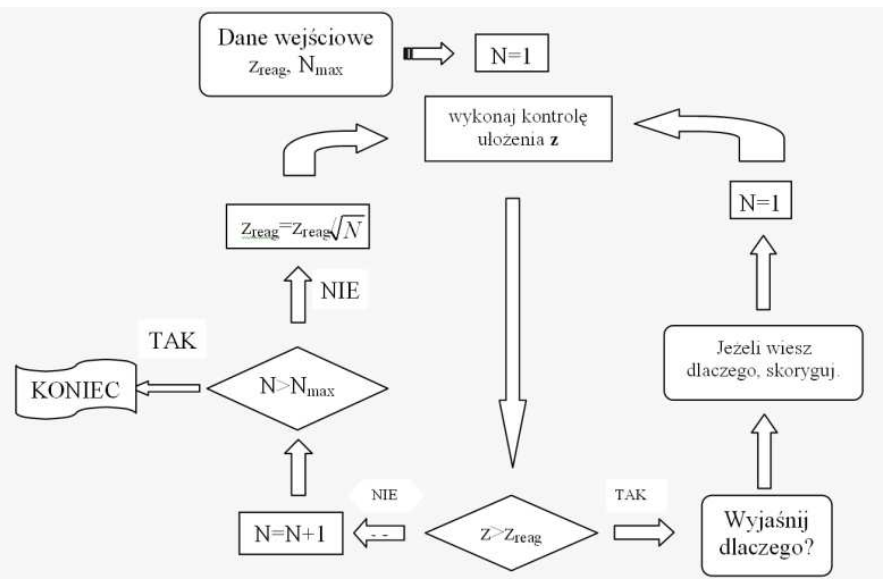

Rycina 4.2. Schemat blokowy metody kontroli $\mathrm{z}$ malejącym progiem reagowania.

W przypadku znalezienia czynnika, który przypuszczalnie wpłynął na ułożenie pacjenta w nieprawidłowy sposób, czynnik ten jest eliminowany i kontrola rozpoczyna się od początku. Jeżeli nie uzyskano wiążącej odpowiedzi na postawione pytanie, co niestety ma często miejsce, to leczenie jest kontynuowane. Zarówno w przypadku, gdy próg reagowania nie został przekroczony oraz, gdy nie udało się wyjaśnić stwierdzonej nieprawidłowości po uzyskaniu wyniku z drugiej kontroli obliczana jest wartość średnia różnicy położenia izocentrum realizowanego i zaplanowanego. Ta średnia (po wykonaniu dwóch kontroli ułożenia to średnia $\mathrm{z}$ dwóch wyników) jest porównywana $\mathrm{z}$ nowym progiem reagowania, którego wartość jest mniejsza od wartości początkowej o czynnik równy pierwiastkowi z dwóch. Dalsze postępowanie jest identyczne $\mathrm{z}$ postępowaniem realizowanym po pierwszej sesji kontrolnej. Systematycznie poziom reagowania zmniejsza się, jak pierwiastek z liczby wykonanych kontroli. Liczba kontroli, po których postępowanie weryfikacyjne jest kończone podejmowana jest arbitralnie $\mathrm{w}$ danym ośrodku radioterapii. Na rycinie 4.2 pokazano schemat blokowy postępowania metody „Shrinking Action Level". 
Jak wyglądałby protokół SAL dla pacjenta nr 2 z Tabeli 3.1. Pierwsza kontrola wykazała różnicę położenia izocentrum realizowanego względem zaplanowanego o wartość $2 \mathrm{~mm}$ (w tabeli $-2 \mathrm{~mm}$ ). Ta wartość jest mniejsza od przyjętego progu reagowania a zatem pacjent kontynuowałby leczenie bez jakiejkolwiek interwencji ze strony zespołu realizującego leczenie. W drugim dniu wartość średnia rozbieżności pomiędzy izocentrum realizowanym i zaplanowanym wyniosła 2,5 mm. Zmniejszony próg reagowania wynosi 2,8 $\mathrm{mm}$ (czyli $4 / \sqrt{2}$ ), a zatem znowu uzyskana rozbieżność nie przekracza tej wartości. Po dwóch kontrolach kończone jest sprawdzanie ułożenia pacjenta $\left(\mathrm{N}_{\max }=2\right)$, a zatem ostatecznie pacjent będzie kontynuował leczenie bez jakichkolwiek zmian $\mathrm{w}$ ułożeniu.

Jakie są różnice pomiędzy obydwoma opisanymi powyżej metodami kontroli ułożenia pacjenta? Metoda NAL proponuje wyznaczenie na podstawie kilku pomiarów błędu systematycznego i korekcję ułożenia pacjenta o wyznaczoną wartość. W metodzie SAL podejmowana jest próba odpowiedzi na pytanie, czy popełniony błąd systematyczny jest większy niż z góry założona wartość, i jeżeli stwierdzi się istnienie takiego błędu, podejmowana jest próba wyjaśnienia zaistniałej sytuacji i ewentualnie dokonywana jest adekwatna korekta ułożenia pacjenta. W metodzie NAL zawsze dokonywana jest korekta ułożenia pacjenta, bez względu na uzyskaną średnią wartość różnicy pomiędzy izocentrum realizowanym i zaplanowanym. Metoda NAL prawdopodobnie pozwala na uzyskanie w całej populacji leczonych pacjentów poprawę jakości leczenia $\mathrm{w}$ trochę większym stopniu niż metoda SAL. Natomiast metoda SAL, ze względu na wprowadzony obligatoryjny element analizy przyczyn błędów daje większą możliwość doskonalenia działalności zespołu przygotowującego i realizującego leczenie. Metoda NAL jest bardzo prosta i nie wymaga żadnych danych wejściowych. W metodzie SAL konieczne jest zgromadzenie pewnej ilości danych, aby ustalić własne progi reagowania. Metoda NAL jest narażona na błędne wykonanie korekcji, co może prowadzić do znaczącego pogorszenia jakości leczenia, np. pomylenie kierunku, w jakim należy wykonać korekcję, co nie jest aż tak bardzo nieprawdopodobne. Bez względu na to, która metoda zostanie zastosowana niezbędne jest uważne przyglądanie się uzyskiwanym wynikom i krytyczne ich analizowanie.

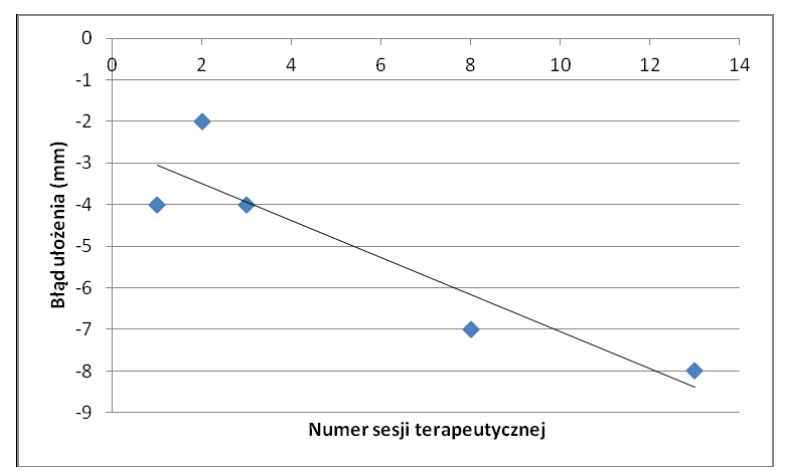

Rycina 4.3. Trend czasowy wpływający na pogarszającą się odtwarzalność ułożenia pacjenta.

\subsection{Metoda extended No Action Level (eNAL)}

W obydwu metodach po kilku początkowych sesjach terapeutycznych leczenie jest kontynuowane bez weryfikacji. Wyrażane są obawy, czy takie postępowanie jest zasadne. Źródłem tego niepokoju jest nie tylko możliwość błędnego obliczenia wartości średniej, ale również możliwość występowania tzw. trendów czasowych. W przypadku występowania trendu czasowego w sposób stały w czasie, w jednym kierunku zmienia się położenie izocentrum realizowanego względem układu pacjenta. Jak wykazała analiza wyników kontroli ułożenia dla pacjentów leczonych w Świętokrzyskim Centrum Onkologii, pod kątem istnienia trendów czasowych, zjawisko to jest stosunkowo rzadkie. Niemniej zasadne jest uważne obserwowanie zachowania każdego pacjenta, czy zastosowane unieruchomienia spełniają swoją rolę, np. poprzez odczytywanie aktualnego SSD. Gdy zauważymy, że w trakcie trwania leczenia pacjent ma duże możliwości ruchu głową $\mathrm{W}$ masce unieruchamiającej to najprawdopodobniej pacjent schudł, co może skutkować stałą zmianą położenia izocentrum. Podobnie, jeżeli zauważona zostanie zmiana w wartościach SSD, to należy przypuszczać, że zmieniły się wymiary ciała pacjenta, co może również prowadzić do zmiany położenia izocentrum. Na rycinie $\mathbf{4 . 3}$ pokazano wyniki kontroli ułożenia dla pacjenta leczonego $\mathrm{w}$ jednym ze szpitali. Wykres dobrze ilustruje trend czasowy. Aby uwzględnić występowanie trendów czasowych grupa $\mathrm{z}$ Rotterdamu rozszerzyła metodę NAL o dodatkowy element. Ten nowy schemat postępowania nazwała jako ,extended No Action Level - eNAL". W tym schemacie w każdym kolejnym tygodniu leczenia wykonywana jest dodatkowa kontrola ułożenia pacjenta. Do czasu wykonania kontroli w drugim tygodniu sposób postępowania jest identyczny jak w schemacie NAL. Po wykonaniu dodatkowej kontroli w kolejnym tygodniu do wszystkich uzyskanych wyników dopasowywana jest prosta (zależność przesunięcie izocentrum w funkcji sesji terapeutycznej dla każdego kierunku oddzielnie) i wyznaczana jest nowa wartości korekcji ułożenia, której wartość jest równa wartości funkcji liniowej wyznaczonej dla sesji terapeutycznej, w której dodatkowo wykonano kontrolę. W ośrodku w Rotterdamie kontrole są wykonywane w 1, 2 i 3 sesji terapeutycznej a następnie w 8, 13 itd. W tym przypadku pierwsza wartość korekcji położenia izocentrum jest wykonywana na podstawie pomiarów wykonanych w sesjach 1,2 i 3 . Następnie po wykonaniu pomiaru w sesji 8 dopasowywana jest prosta $\mathrm{f}(\mathrm{N})$, gdzie $\mathrm{N}$ to numer sesji terapeutycznej. W sesjach od 9 do 13 włącznie położenie izocentrum jest korygowane o wartość $f(8)$. Po wykonaniu kontroli w sesji 13 ponownie wykonywane jest dopasowanie prostej $g(N)$ do wszystkich wyników i od sesji 14 do 18 położenie izocentrum jest korygowane o wartość g(13). Do oznaczenia funkcji liniowej po uzyskaniu wyniku kontroli w sesji nr 13 użyto innego oznaczenia, mianowicie „g”, gdyż kolejne dopasowanie może prowadzić do uzyskania innej postaci funkcyjnej prostej. Takie postępowanie jest kontynuowane do 
zakończenia leczenia. Wdrożenie tej metody kontroli ułożenia jest dość pracochłonne i dlatego jest dość rzadko stosowane. Na rycinach 4.4abc zilustrowano graficznie metodę eNAL.

\subsection{Metody mieszane}

Dwie prezentowane metody kontroli ułożenia NAL i SAL nie różnią się znacząco od siebie. W Świętokrzyskim Centrum Onkologii (ŚCO) oraz w Centrum Onkologii w Warszawie na Ursynowie wykorzystano obydwie metody do opracowania metody, którą można wdrożyć we wszystkich tych ośrodkach, w których możliwe jest kontrolowanie on-line ułożenia pacjenta. W ŚCO $\mathrm{w}$ trakcie pierwszych trzech sesji terapeutycznych wykonywana jest kontrola on-line. Jeżeli realizowane położenie izocentrum różni się dla któregokolwiek kierunku o więcej niż arbitralnie przyjęty próg reagowania, który może zależeć od lokalizacji, technicy przed włączeniem wiązki terapeutycznej dokonują stosownego przesunięcia stołu terapeutycznego. Dalej postępowanie jest realizowane zgodnie $\mathrm{z}$ procedurą NAL. W ŚCO, w drugim tygodniu leczenia wykonywana jest jeszcze jedna dodatkowa kontrola. Jeżeli w wyniku tej kontroli różnica pomiędzy izocentrum realizowanym i zaplanowanym w którymkolwiek kierunku przekracza podwojoną wartość błędu przypadkowego wyznaczonego dla grupy pacjentów tj. $\left(2 \mathrm{X}_{\text {przyp }}, 2 \mathrm{Y}_{\text {przyp }}, 2 \mathrm{Z}_{\text {przyp }}\right)$, to uznaje się, że konieczne jest dalsze prowadzenie kontroli ułożenia pacjenta. Najpierw przeprowadza się analizę, aby znaleźć przyczyny wystąpienia tak dużej różnicy i bez względu na to, czy została ona wykryta, czy nie, rozpoczyna się kontrolę od początku.

\section{Analiza jakościowa}

Dotychczas skupiono się na analizie ilościowej, na wyznaczeniu błędów systematycznych i przypadkowych. Obok analizy ilościowej ważną rolę odgrywa analiza jakościowa. Zmiana położenia izocentrum pól terapeutycznych względem układu pacjenta może być wyznaczona na podstawie porównania dowolnej pary prostopadłych zdjęć portalowych i pól odniesienia, dla których początek układu współrzędnych znajduje się w tym samym miejscu w jakim znajduje się początek układu współrzędnych pól terapeutycznych. W żargonie takie pola nazywane są polami weryfikacyjnymi. Takie postępowanie jest stosowane dość powszechnie, gdyż albo pola terapeutyczne są zbyt małe i nie zawierają struktur anatomicznych mogących służyć do weryfikacji ułożenia, albo wśród pól terapeutycznych nie ma pól prostopadłych, co utrudnia wyznaczenia wszystkich trzech współrzędnych wektora translacji albo jakość obrazów utrudnia jednoznaczne określenie zgodności ułożenia.

W prawidłowo prowadzonej kontroli ułożenia niezwykle ważne jest sprawdzenie kształtu wszystkich pól terapeutycznych i obszaru tkanek jaki te pola obejmują. Taką kontrolę powinien przeprowadzić lekarz odpowiedzialny za leczenie pacjenta. Zobowiązuje go do tego rozporządzenie ministra zdrowia $\mathrm{W}$ sprawie bezpiecznego stosowania

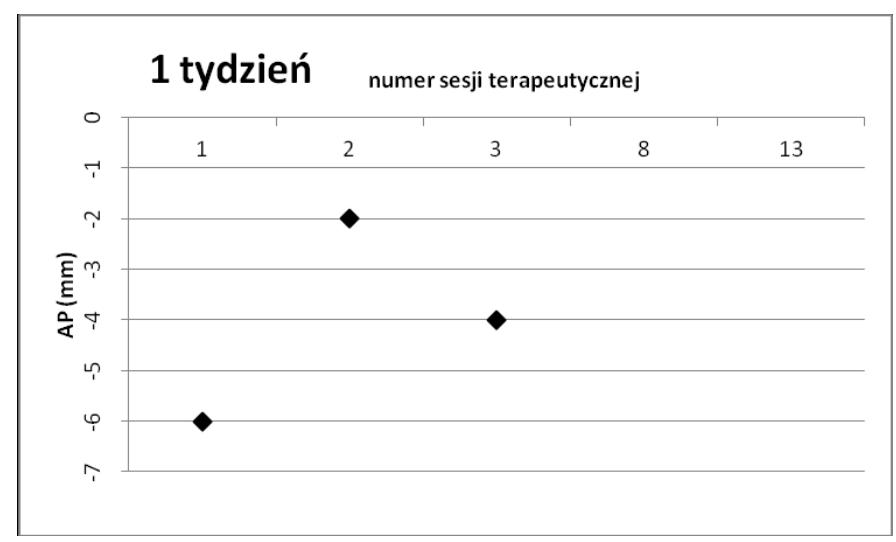

Rycina 4.4a. Wartość średnia $\mathbf{- 4 , 0} \mathrm{mm}$. Korekta w kolejnym tygodniu o wartość $4,0 \mathrm{~mm}$.

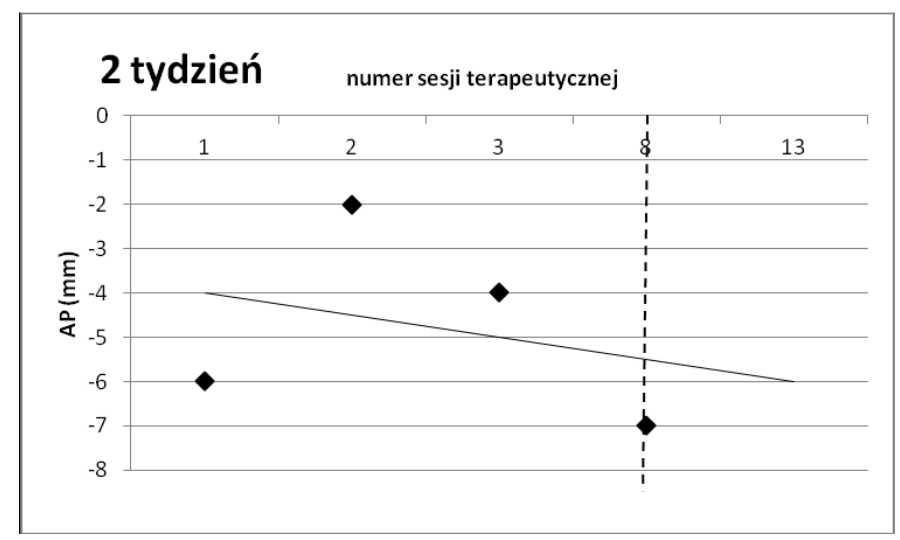

Rycina 4.4b. Ekstrapolowana wartość średnia $-5,5 \mathrm{~mm}$. Korekta w kolejnym tygodniu o wartość $5,5 \mathrm{~mm}$.

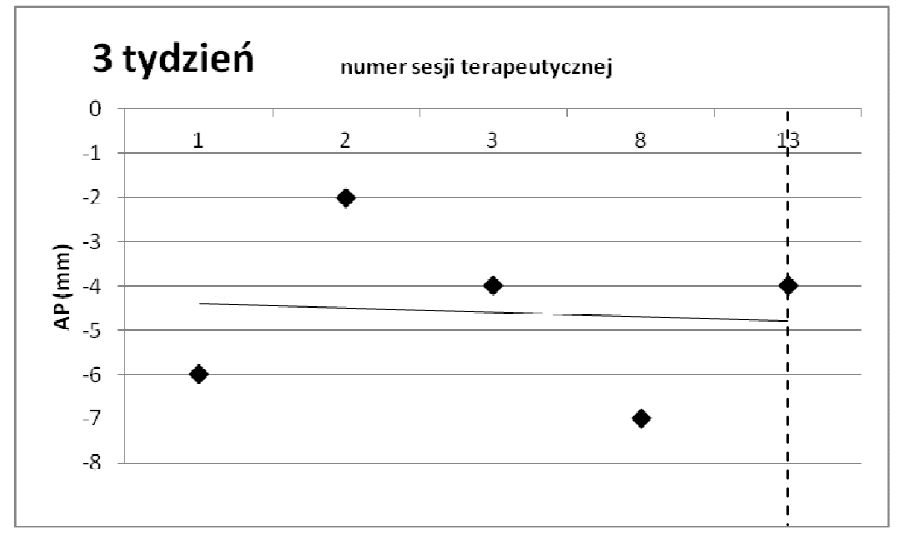

Rycina 4.4c. Ekstrapolowana wartość średnia -4,8 mm. Korekta w kolejnym tygodniu o wartość $4,8 \mathrm{~mm}$.

promieniowania jonizującego. Wzrokowa ocena pól terapeutycznych nie dostarcza informacji ilościowej, ale pozwala uniknąć dużych błędów geometrycznych, np. na realizacji niewłaściwego planu leczenia. Należy jeszcze raz podkreślić, że analiza ilościowa nie może zastępować analizy jakościowej. Za tę drugą odpowiada lekarz radioterapeuta prowadzący leczenie, który powinien uczestniczyć w pierwszej sesji terapeutycznej.

\section{Techniczne aspekty kontroli ułożenia}

Omawiając zagadnienie weryfikacji prawidłowości ułożenia pacjenta posługiwano się $\mathrm{w}$ tym celu dwoma układami współrzędnych, układem współrzędnych pacjenta i wiązki 
terapeutycznej. Ten pierwszy układ był najczęściej wyznaczony poprzez układ kostny. $\mathrm{W}$ istocie rzeczy terapia powinna być zrealizowana w taki sposób, aby zlecona dawka została zaabsorbowana przez tę objętość tkanek, która została zaklasyfikowana, jako objęta procesem nowotworowym (objętość tarczowa). Czy zatem układ kostny jednoznacznie określa położenie guza nowotworowego (ściśle objętości tarczowej)? W pewnych przypadkach tak, w innych niestety położenie guza nie jest jednoznacznie związane z układem kostnym. Np. w wielu badaniach wykazano, że położenie gruczołu krokowego jest dość słabo związane z kośćmi miednicy. W takim przypadku w kontroli ułożenia pacjenta nie wystarczy wykonać zdjęcie rentgenowskie, które określać będzie wzajemne położenie pola terapeutycznego i struktur kostnych. Należy sięgnąć po metody, które pozwolą zobrazować położenie gruczołu krokowego (tkanki miękkiej!) względem pola terapeutycznego. Obecnie dzięki różnym technicznym rozwiązaniom możliwe jest rejestrowanie położenia tkanek miękkich a nawet możliwe jest śledzenie położenia ruchomych guzów, np. zmian nowotworowych w płucach. W tym paragrafie przedstawione zostaną różne rozwiązania techniczne, umożliwiające wizualizację struktur kostnych oraz tkanek miękkich stosowane w kontroli ułożenia pacjenta.

\subsection{Rozwiązania umożliwiające zobrazowanie struktur kostnych}

Najprostszym detektorem promieniowania używanym w kontroli ułożenia jest film rtg. Zasadniczą wadą tego rozwiązania jest konieczność wywołania filmu, co uniemożliwia w praktyce kontrolę on-line a zatem uniemożliwia wykrycie i skorygowanie dużych błędów. Dodatkowo jest to metoda czasochłonna. Filmy rtg w chwili obecnej, w krajach rozwiniętych, zostały wyparte przez elektroniczne urządzenia do kontroli obrazowej ułożenia. Po angielsku są one określane terminem Electronic Portal Imaging Device - EPID. Elektroniczny portal jest integralną częścią akceleratora medycznego. $\mathrm{Na}$ rycinie $\mathbf{6 . 1}$ pokazano przykładowy EPID zamontowany na ramieniu akceleratora firmy Siemens.

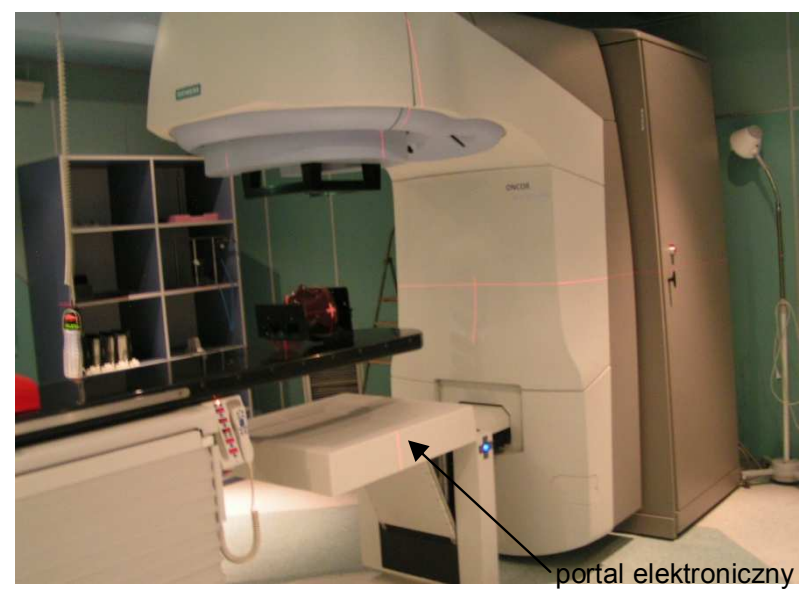

Rycina 6.1. Portal elektroniczny zainstalowany na akceleratorze Oncor firmy Siemens w pozycji roboczej.
Detektor jest umieszczany automatycznie w pozycji roboczej, lub chowany do pozycji postojowej. W najnowocześniejszych EPID'ach stosowane są detektory zbudowane na bazie amorficznego krzemu. Ten detektor pozwala uzyskać wysoką rozdzielczość i zapewnia duży obszar czynny detektora. Dawka jaką należy dostarczyć pacjentowi, aby otrzymać dobrej jakości obraz zwykle nie przekracza 2 cGy. Tak niska wartość dawki pozwala na uzyskanie obrazu po podaniu już niewielkiej części dawki całkowitej przewidzianej dla pojedynczego pola terapeutycznego, co ułatwia wdrożenie kontroli on-line. Każdy $\mathrm{z}$ producentów akceleratorów dostarcza specjalizowane oprogramowanie do analizy obrazów portalowych i do nakładania obrazów portalowych na obrazy odniesienia. Podstawowym narzędziem takiego oprogramowania jest wprowadzanie konturów, czyli brzegów struktur widocznych na obrazach. Po wprowadzeniu brzegów widocznych i wiarygodnych konturów obraz odniesienia jest nakładany w taki sposób, aby kontury $\mathrm{z}$ obrazu portalowego pokryły się $\mathrm{Z}$ konturami na obrazie odniesienia. Po wykonaniu tej operacji system automatycznie podaje informację o wektorze przesunięcia i ewentualnie rotacji obydwu obrazów. Po wykonaniu jednego zdjęcia portalowego uzyskiwana jest informacja o wektorze przesunięcia $w$ dwóch kierunkach reprezentowanych na płaszczyźnie zdjęcia i jednym kącie obrotu. Brakuje informacji o trzecim, prostopadłym kierunku do tych dwóch i drugim kącie obrotu. Uzyskanie tej informacji jest możliwe poprzez wykonanie zdjęcia ortogonalnego. Warto zauważyć, że jeden $\mathrm{z}$ kierunków jest reprezentowany na obydwu zdjęciach. Składowa wektora przesunięcia na obydwu zdjęciach powinna mieć bardzo podobną wartość. Poprzez porównanie tych dwóch wartości można zweryfikować poprawność nałożenia struktur.

Wykonanie dwóch zdjęć ortogonalnych wymaga obrócenia głowicy aparatu, co wydłuża proces kontroli ułożenia. Proponowane jest inne rozwiązanie, w którym na głowicy urządzenia terapeutycznego montowane jest dodatkowe źródło promieniowania rtg o osi prostopadłej do osi wiązki terapeutycznej. Taka konstrukcja umożliwia jednoczasowe wykonanie dwóch ortogonalnych zdjęć. Inne analogiczne rozwiązanie techniczne polega na zamontowaniu dwóch źródeł promieniowania rtg wytwarzających dwie niewspółosiowe wiązki promieniowania rtg (kąt miedzy dwoma wiązkami jest zbliżony do kąta prostego), niezależnie od głowicy aparatu. Takie rozwiązanie o nazwie Novalis jest proponowane przez firmę BrainLab. Zaletą tych rozwiązań, poza skróceniem czasu wykonania kontroli ułożenia, jest uzyskanie bardzo dobrej jakości zdjęć weryfikacyjnych, znakomicie obrazujących struktury kostne (promieniowanie rtg). Wadą natomiast konieczność wykonywania dodatkowych kontroli geometrii urządzeń i stosunkowo niewielki obszar jaki można zobrazować.

Rewolucyjne rozwiązanie w dziedzinie kontroli ułożenia pacjenta wprowadziła Elekta. Zaproponowała ona użycie dodatkowego źródła rtg zamontowanego na głowicy akceleratora umożliwiającego wykonanie tomografii 
komputerowej u pacjenta leżącego w pozycji terapeutycznej. Zasadnicza różnica względem klasycznej tomografii polega na tym, że uzyskiwanie informacji obrazowej odbywa się za pomocą szerokiej wiązki stożkowej a nie wąskiej wiązki (zastosowanie wąskiej wiązki $\mathrm{w}$ badaniach diagnostycznych wymusza ruch stołu diagnostycznego, aby wykonać obrazowanie w odpowiednio dużym obszarze). Obraz uzyskany za pomocą wiązki stożkowej ma gorszą jakość niż uzyskany w klasycznych tomografach, jednakże wystarczająco dobrą, aby była możliwość obrazowania tkanek miękkich. $\mathrm{Na}$ rycinie 6.2 pokazano akcelerator firmy Varian $\mathrm{z}$ zainstalowanym układem do kontroli ułożenia wiązką stożkową.

Uzyskane obrazy tomograficzne są analizowane poprzez porównanie $\mathrm{z}$ obrazami tomograficznymi użytymi do planowania leczenia. W tym celu każdy producent dostarcza odpowiednie specjalizowane oprogramowanie. Standardowo obrazy są prezentowane w trzech projekcjach poprzecznej, strzałkowej i czołowej. Zadaniem użytkownika jest nałożyć na siebie dwa zestawy obrazów z planowania leczenia i z kontroli ułożenia, tak, aby jak najwierniej pasowały do siebie. Zwykle oprogramowanie umożliwia automatyczne nałożenie obrazów. Działa ono dobrze dla struktur anatomicznych o dużym kontraście (kości). Dla pozostałych struktur niezbędne jest włączenie się użytkownika w proces nakładania obrazów. Zasadnicza różnica pomiędzy systemami opartymi o płaskie obrazy i rozwiązaniami z zastosowaniem wiązki stożkowej polega na tym, że obrazy tomograficzne pozwalają na nakładanie obrazów uwzględniają również tkanki miękkie. Sam proces nakładania nie jest łatwy i wymaga dużego doświadczenia.

Firma Siemens dostarczała rozwiązanie tomograficzne, w którym informacja obrazowa jest uzyskiwana $\mathrm{z}$ użyciem promieniowania megawoltowego - tzw. tomografia megawoltowa. Zaletą tego rozwiązania jest jego stosunkowo niska cena urządzenia i fakt, że obrazy są uzyskiwane za pomocą tej samej wiązki, którą pacjent będzie napromieniany, co znacząco upraszcza kontrolę jakości. Wadą jest to, że promieniowanie megawoltowe pozwala na wizualizację jedynie struktur kostnych, chyba, że podana dawka promieniowania jest wysoka - około 30 cGy. Firma Siemens proponuje również rozwiązanie polegające na zainstalowaniu w pomieszczeniu terapeutycznym jezdnego tomografu (często to urządzenie jest określane jako tomograf na szynach). $\mathrm{Na}$ rycinie 6.3 pokazano jezdny tomograf zainstalowany w ŚCO. Słowo ,jezdny” określa możliwość ruchu translacyjnego okola tomografu. Pacjent pozostaje nieruchomy na stole terapeutycznym. Skanowanie odbywa się poprzez ruch okola wzdłuż stołu terapeutycznego, na którym spoczywa pacjent. Niedogodnością tego rozwiązania jest wydłużenie kontroli ułożenia pacjenta związane $\mathrm{z}$ koniecznością dwukrotnego obrotu stołu terapeutycznego. Zaletą jakość obrazu, identyczna z jakością obrazów użytych do planowania leczenia.

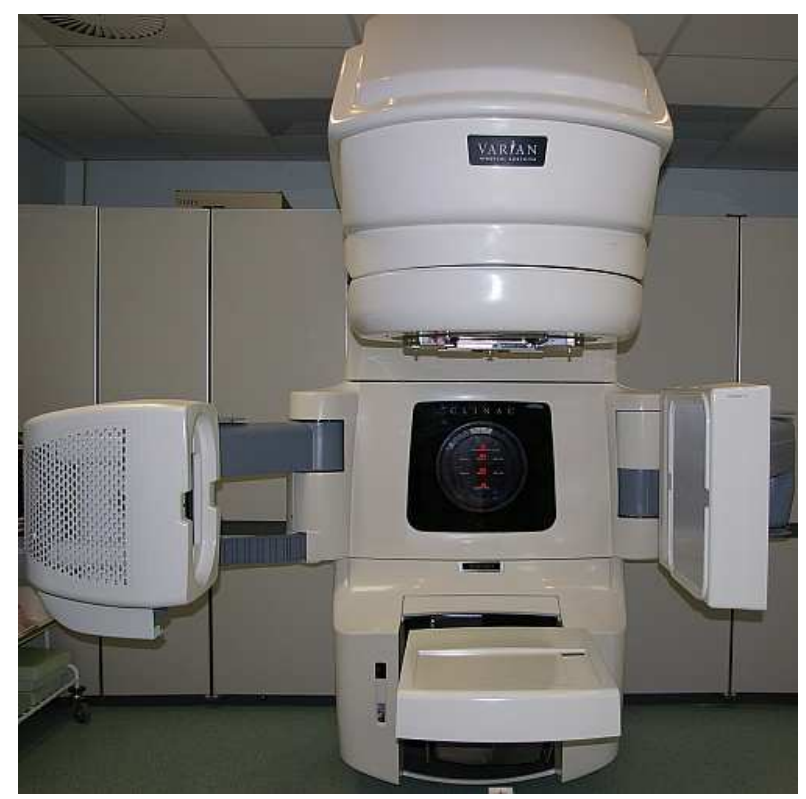

Rycina 6.2. Akcelerator firmy Varian z zainstalowanym systemem do kontroli ułożenia z użyciem wiązki stożkowej.

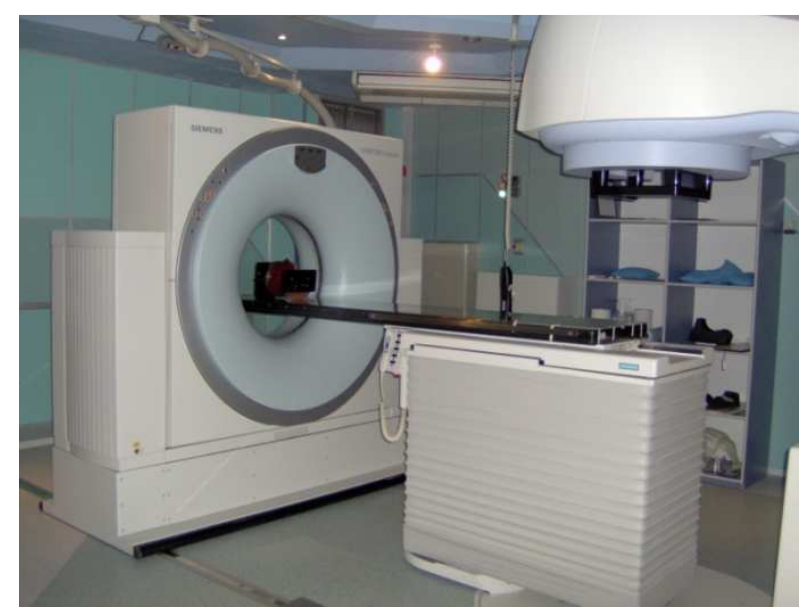

Rycina 6.3. Tomograf jezdny firmy Siemens zainstalowany w Świętokrzyskim Centrum Onkologii współpracujący z akceleratorem Oncor.

We wszystkich prezentowanych powyżej rozwiązaniach kontrola ułożenia pacjenta jest przeprowadzana poprzez porównanie obrazu struktur anatomicznych uzyskanego przed napromienianiem $\mathrm{z}$ odpowiednim obrazem uzyskanym w czasie planowania leczenia.

Ze względu na ograniczoną jakość obrazów uzyskiwanych podczas weryfikacji, szczególnie w przypadku obrazowania tkanek miękkich i związane $\mathrm{z}$ tym faktem trudności w nakładaniu obrazów zaproponowano, aby w obszar zmiany nowotworowej wprowadzać złote znaczniki. Obecnie stosowane złote znaczniki mają średnicę poniżej $2 \mathrm{~mm}$ i długość około $6 \mathrm{~mm}$. Złoto, jako absorbent o wysokim $\mathrm{Z}$ jest dość dobrze widoczne zarówno na zdjęciach rtg jak i na zdjęciach megawoltowych. Dodatkową, najważniejszą zaletą takiego rozwiązania jest możliwość stosunkowo szybkiego i łatwego nałożenia obrazu $\mathrm{z}$ etapu planowania leczenia $\mathrm{z}$ obrazem wykonanym w czasie terapii. Dużo łatwiej dopasowywać pojedyncze znaczniki niż struktury anatomiczne. W przypadku, gdy zdjęcia kontrolujące ułożenie pacjenta są wykonywane 
z użyciem dodatkowych źródeł promieniowania, można niemal on-line rejestrować położenie znaczników. Takie rozwiązanie ma szczególne znaczenie w terapii guzów, których położenie w trakcie napromieniania ulega zmianie ze względu na ruchy fizjologiczne. Złote znaczniki znalazły szerokie zastosowanie $\mathrm{w}$ terapii pacjentów $\mathrm{z}$ nowotworem gruczołu krokowego. Innym bardzo dobrym przykładem takiej sytuacji jest terapia $\mathrm{w}$ rejonie przepony. Część guzów płuca zmienia swoje położenie nawet o kilka centymetrów $\mathrm{z}$ powodu ruchów oddechowych. Firma Accuray opracowała aplikację, która w oparciu o wykonywane zdjęcia rtg $\mathrm{z}$ dwóch prostopadłych źródeł pozwala na rejestrację znaczników w czasie rzeczywistym. Informacja o aktualnym położeniu znaczników jest przesyłana do układu silników sterujących położeniem głowicy akceleratora, co pozwala ,śledzić” położenie guza.

W celu zobrazowania położenia złotych znaczników w ciele pacjenta niezbędne jest wykonanie zdjęcia rtg, a zatem są to znaczniki pasywne, same znaczniki nie pozwalają na uzyskanie informacji o położeniu śledzonego narządu w czasie rzeczywistym. Najnowszym osiągnięciem w kontroli położenia guza nowotworowego są aktywne znaczniki tzw. transpondery. Są to elektroniczne elementy, które absorbują energię fali elektromagnetycznej i następnie emitują ją. Sygnał wysyłany przez transpondery jest rejestrowany przez antenę, która określa ich przestrzenną lokalizację względem izocentrum przyspieszacza liniowego. System ten można określić jako mikro system GPS. Transpondery mają podobny rozmiar jak złote znaczniki. Niepewność określenia położenia transponderów nie przekracza ułamka mm. Sygnał jest emitowany z transponderów z częstotliwością $10 \mathrm{~Hz}$ (w najnowszych rozwiązaniach $25 \mathrm{~Hz}$ ), co umożliwia detekcję zmian położenia objętości tarczowej w czasie rzeczywistym. Szczególnie ważnym obszarem zastosowania transponderów wydaje się być terapia pacjentów $\mathrm{z}$ nowotworem gruczołu krokowego. Właśnie zastosowanie transponderów umożliwiło poznanie zależności czasowych w ruchu gruczołu krokowego i ukazało jak duże trudności wiążą się $\mathrm{z}$ terapią tej grupy pacjentów. Należy oczekiwać, że transpondery będą znajdowały coraz szersze zastosowanie w radioterapii. Jedynym poważnym mankamentem tego rozwiązania, podobnie zresztą jak złotych znaczników jest inwazyjność metody i w chwili obecnej bardzo wysoka cena.

\section{Praktyka kontroli ułożenia}

Przedstawiona w poprzednich paragrafach szeroka wiedza na temat kontroli portalowej pozwala opracować własny system kontroli ułożenia pacjenta. W tym paragrafie zawarte zostaną minimalne wymagania, jakie zdaniem autora reprezentującego PTFM powinny być realizowane w każdym ośrodku radioterapii prowadzącym terapię $\mathrm{z}$ użyciem wiązek zewnętrznych $\mathrm{w}$ leczeniu pacjentów $\mathrm{z}$ chorobą nowotworową. Należy podkreślić, że kontrola ułożenia pacjenta jest wymagana prawem. Takie wymaganie stawia Rozporządzenie Ministra Zdrowia w sprawie warunków bezpiecznego stosowania promieniowania jonizującego dla wszystkich rodzajów ekspozycji medycznej. Rozporządzenie nakłada obowiązek „wykonania weryfikacji obrazowej ułożenia pacjenta na aparacie terapeutycznym, co najmniej przed pierwszym seansem oraz jeżeli to technicznie możliwe, wykonania zdjęć sprawdzających dla pól terapeutycznych podczas pierwszego lub drugiego seansu każdego etapu leczenia". W zaleceniach PTFM zwrócona zostanie szczególna uwaga na ilościowe podejście do kontroli ułożenia pacjenta oraz na zbudowanie systemu zapewniającego właściwy przepływ i analizę danych.

\subsection{Uczestnicy kontroli ułożenia i ich zadania}

W kontrolę ułożenia pacjenta powinni być zaangażowaniu lekarze radioterapeuci, technicy radioterapii i fizycy medyczni. Jakkolwiek z punktu widzenia technicznego nie ma potrzeby angażowania tak wielu osób w wykonanie kontroli ułożenia pacjenta, to jednak sprawą kluczową $\mathrm{W}$ zbudowaniu właściwego systemu kontroli ułożenia jest ustalenie zasad współpracy pomiędzy wszystkimi podmiotami uczestniczącymi $\mathrm{w}$ przygotowaniu i realizacji radioterapii. Lekarze radioterapeuci ponoszą odpowiedzialność za leczenie pacjenta $\mathrm{i}$ oni, w oparciu o uzyskane informacje $\mathrm{z}$ kontroli ułożenia, podejmują decyzję o dalszym postępowaniu. Zadaniem dwóch pozostałych grup zawodowych jest przeprowadzanie kontroli ułożenia i dostarczenie wyników. W każdym ośrodku radioterapii należy ustalić schemat przepływu informacji pomiędzy poszczególnymi grupami, w szczególności zasady informowania lekarzy o wynikach kontroli ułożenia i określić zasady podejmowania decyzji wynikających z uzyskanych wyników. W sytuacji uzyskania niesatysfakcjonujących wyników tylko lekarz radioterapii może podjąć decyzję o kontynuacji lub wstrzymaniu napromieniania. Szczególną rolą techników radioterapii jest rzetelne wykonywanie kontroli portalowej i bez względu na obowiązujące procedury, co najmniej jakościowe, przeanalizowanie w czasie rzeczywistym wyników, jakie zostały uzyskane. Żadne wyniki nie mogą być pozostawione, bez co najmniej wzrokowej analizy uzyskanych obrazów. Takie postępowanie ma za zadanie nie dopuścić do popełnienia dużych błędów w napromienianiu pacjenta. Szczególną rolą fizyków medycznych jest analiza ilościowa otrzymywanych wyników kontroli ułożenia.

W budowaniu systemu kontroli ułożenia PTFM zaleca postępować analogicznie do zasad wdrożonych w radiologii określonych terminem ,analiza zdjęć odrzuconych”. W takich działaniach powinny uczestniczyć wszystkie grupy zawodowe lekarze radioterapeuci, technicy radioterapii i fizycy medyczni. Szczegółowe zalecenia dotyczące analizy wyników kontroli portalowej zostaną przedstawione $\mathrm{w}$ dalszej części tego opracowania. 


\subsection{Obrazowe dane wejściowe do kontroli ułożenia pacjenta}

Niniejsze opracowanie dotyczy tylko i wyłącznie obrazów płaskich, aczkolwiek bardzo łatwo rozszerzyć je na wyniki uzyskiwane $\mathrm{z}$ użyciem systemów, w których wyniki kontroli ułożenia są uzyskiwane z użyciem systemów tomograficznych. Danymi wejściowymi mogą być jedynie obrazy odniesienia wytworzone $\mathrm{z}$ użyciem informacji obrazowej użytej do przygotowania planu leczenia. W przypadku planów leczenia przygotowywanych $\mathrm{z}$ użyciem tomografii komputerowej powinny to być rekonstrukcje radiograficzne. Jakość rekonstrukcji radiograficznych zależy głównie od grubości warstw tomograficznych użytych do planowania leczenia. Zaleca się, aby odległość pomiędzy przekrojami nie przekraczała $0,3 \mathrm{~cm}$. Taka gęstość przekrojów pozwala uzyskać obrazy zrekonstruowane o wysokiej jakości. Ostateczna decyzja o gęstości wykonywanych badań tomograficznych jest podejmowana przez użytkownika i zwykle zależy od lokalizacji. W przypadku terapii stereotaktycznej prowadzonej w rejonie mózgowia zwykle odległość pomiędzy przekrojami nie przekracza $2 \mathrm{~mm}$.

Zaleca się, aby zawsze przed pierwszym użyciem klinicznym obrazów odniesienia przeprowadzić testy sprawdzające poprawność generowania obrazów odniesienia. Taki test można przeprowadzić z użyciem fantomu antropomorficznego.

Jeżeli tylko plan leczenia na to pozwala, należy, co najmniej wygenerować dwa obrazy odniesienia dla dwóch prostopadłych kierunków. Preferowane są obrazy wygenerowane dla pól terapeutycznych. W szczególnej sytuacji, gdy plan leczenia nie zawiera pól ortogonalnych, lub, gdy pola terapeutyczne nie uwidaczniają struktur anatomicznych typu podstawowego (o typach struktur czytelnik znajdzie informacje w ostatniej części tych zaleceń), w celu wygenerowania obrazów odniesienia zaleca się postępować w sposób następujący. W pierwszej kolejności należy poszerzyć pola terapeutyczne, tak, aby widoczne były struktury typu podstawowego. Poszerzając obrazowany obszar należy postępować w taki sposób, aby uzyskać oczekiwany rezultat minimalizując obszar tkanek poddanych ekspozycji. Jeżeli z jakichś powodów takie działanie nie przynosi zadowalającego efektu, należy wygenerować niezależne, ortogonalne pola zaczepione w punkcie izocentrum określonym w planie leczenia. Obrazy tych pól powinny zawierać struktury typu podstawowego. $\mathrm{Z}$ taką sytuacją spotykamy się na przykład w napromienianiu loży po guzie u pacjentek leczonych $\mathrm{z}$ powodu nowotworu piersi. Bez względu na sytuację, nawet wtedy, gdy nie zawierają one widocznych struktur anatomicznych, wypełniając wymagania prawne, należy wygenerować pola odniesienia dla pól terapeutycznych. Umożliwia to sprawdzenie kształtu i orientacji pól terapeutycznych. Wyjątek może stanowić sytuacja, gdy pacjent jest leczony techniką IMRT, w której nie istnieją pola terapeutyczne w takim samym rozumieniu, jak $\mathrm{w}$ technice $3 \mathrm{D}$. W takiej sytuacji nie jest możliwe wykonanie kontroli dla pól terapeutycznych. Można natomiast sprawdzić, przy zastosowaniu utworzonych pól weryfikacyjnych, zgodność realizowanego z zaplanowanym izocentrum. Dodatkowo dobierając odpowiednią wielkość pól możliwe jest sprawdzenie prawidłowości napromienianego obszaru w kierunku głowa-nogi.

Zaleca się, o ile takie działanie pozwoli na skrócenie czasu dopasowania obrazów odniesienia i sprawdzających, wrysowanie konturów struktur typu podstawowego i ewentualnie pomocniczego na obrazach odniesienia. Jeżeli posiadane oprogramowanie do nakładania obrazów umożliwia zastosowanie filtrów poprawiających kontrast obrazów, warto jest, dla poszczególnych lokalizacji, przetestować i wskazać filtry, które uwidaczniają w lepszy sposób struktury typu podstawowego i pomocniczego na obrazach.

\subsection{Niepewność kontroli ułożenia}

Z oczywistych powodów uzyskanie w każdej sesji terapeutycznej ułożenia pacjenta zgodnego z zaplanowanym nie jest możliwe. Czy każda różnica pomiędzy obrazem odniesienia i obrazem portalowym wskazuje na błąd w realizacji radioterapii? Niekoniecznie. Kontrola ułożenia to działalność pomiarowa (doświadczalna). Każdy uzyskany wynik jest obarczony niepewnością. Do podstawowych czynników wpływających na niepewność pomiaru (tzw. budżet niepewności) należą: 1) ograniczenia wynikające $\mathrm{z}$ faktu, że dwa dopasowywane obiekty nie są identyczne, 2) arbitralność nakładania obrazów (umiejętności zespołu), 3) ograniczona dokładność posiadanych narzędzi, 4) jakość porównywanych obrazów. Z założenia jednoznaczne przekształcenie afiniczne (translacje, obroty) jest możliwe jedynie dla dwóch identycznych obiektów. Ze względu na to, że ciało człowieka nie jest bryłą sztywną, nałożenie (dopasowanie) dwóch obrazów odbywa się zawsze poprzez minimalizację jakiejś funkcji podobieństwa. Nawet wtedy, gdy nałożenie jest dokonywane arbitralnie przez użytkownika w procesie wzrokowego dopasowania dwóch obrazów jest ono realizowane, aczkolwiek w pewnym sensie nieświadomie, właśnie w taki sposób. Osoby wykonujące kontrolę ułożenia doskonale znają sytuacje, w których muszą zdecydować, które struktury anatomiczne zostaną nałożone na siebie (fragmenty struktur), kosztem gorszego dopasowania innych struktur. W sytuacji, w której użytkownik stwierdzi znaczne różnice w kształcie nakładanych obiektów realizowane są dwa odmienne scenariusze. Pierwszy polega na uśrednieniu nałożenia w całym obszarze obrazu. Drugi polega na wyborze, albo najbardziej wiarygodnych struktur lub ich części, albo na wyborze struktury, która $\mathrm{z}$ punktu widzenia klinicznego odgrywa najważniejszą rolę. Na przykład można w pierwszej kolejności nakładać te struktury, które rzutują się na obszar guza nowotworowego (uzyskanie kontroli miejscowej zależy w największym stopniu od podania dawki terapeutycznej w obszar guza). Trudno podać jakieś uniwersalne zasady postępowania. Tym niemniej w każdym ośrodku takie zasady powinny być opracowane. Niepewność związana $\mathrm{z}$ arbitral- 
nością podejmowania decyzji, z umiejętnościami zespołu może być przedmiotem systematycznego badania, które dostarczy informacji liczbowej o niepewności pomiaru. W tym celu należy przygotować komplet danych do kontroli ułożenia $\mathrm{z}$ użyciem fantomu antropomorficznego. Następnie należy wykonać kontrolę ułożenia, układając fantom w pozycji $\mathrm{z}$ odgórnie określonym, odpowiadającym obserwowanym w codziennej praktyce błędem i przeprowadzić kontrolę ułożenia. Wielokrotne powtórzenie takiego postępowania w kilku wybranych lokalizacjach pozwala ustalić błąd związany z użytkownikiem. Jak we wszystkich działaniach, w których używane są obrazy, niepewność pomiaru w dużym stopniu zależy od doświadczenia użytkownika. W anglojęzycznej literaturze jest mowa o ,well trained observer” i ,not well trained observer". Składowa niepewności związana z obserwatorem będzie większa $u$ obserwatorów o małym doświadczeniu. $\mathrm{Z}$ praktycznego punktu widzenia warto $\mathrm{W}$ wątpliwych sytuacjach skonsultować dopasowanie obrazów Z osobą doświadczoną. Niemniej wyznaczenie całkowitej niepewności pomiaru związanego z nałożeniem obrazów pozwala określić czułość metody kontroli ułożenia pacjenta. Warto również pamiętać, że całkowita niepewność związana z całym procesem określania błędu ułożenia, wyznaczona $\mathrm{w}$ badaniach fantomowych, niedoszacowuje wartość błędu, gdyż pacjent w odróżnieniu od fantomu nie jest bryła sztywną.

Czasami w dopasowywaniu obrazów są popełniane tzw. grube błędy. Źródłem takiego błędu może być na przykład niestaranna praca osoby nakładającej obrazy. Jest jednak pewna szczególna sytuacja, w której nawet osoba niezwykle rzetelnie realizująca swoją pracę może popełnić gruby błąd. $\mathrm{Ma}$ to miejsce, gdy nakładane struktury mają symetrię powodującą, że nakładając obrazy można na kilka sposobów nałożyć na siebie widoczne struktury. Taka sytuacja występuje na przykład, gdy nakładaną strukturą są trzony kręgosłupa. "Przesunięcie" nakładanego obrazu względem obrazu odniesienia o cały trzon nie jest aż tak bardzo nieprawdopodobne (popełniamy błąd liczbowo o wartości około $3 \mathrm{~cm}$ ). W tym szczególnym przypadku może to mieć bardzo poważne konsekwencje, zagrażające nawet życiu pacjenta (przerwanie rdzenia kręgowego). Dlatego ilekroć osoba nakładająca obrazy zauważy, że struktury, które wybrano do dopasowania obrazów mają symetrię translacyjną powinny $\mathrm{z}$ dużą nieufnością traktować uzyskane wyniki. Najlepszym wyjściem z takiej sytuacji jest przygotowanie takich obrazów, które nie będą obciążane wadą symetrii.

\section{Efektywny schemat postępowania}

Z cała pewnością można wdrożyć efektywny schemat postępowania kontroli ułożenia opierając się na metodzie No Action Level lub w ośrodkach, w których siły i środki pozwalają na to, na schemacie extended No Action Level. Opisany poniżej i przedstawiony na rycinach 8.1 i 8.2 schemat postępowania jest pewną modyfikacją schematu NAL. Przed przystąpieniem do wdrażania kontroli portalowej zaleca się dla każdej lokalizacji ustalić tzw. podstawowy poziom reagowania. $\mathrm{W}$ oparciu o podstawowy poziom reagowania (PPR) W pierwszych trzech sesjach terapeutycznych będą podejmowane decyzje postępowania z pacjentem. Ogólne zasady określania wartości PPR są następujące: PPR powinien być nie mniejszy niż podwojona wartość populacyjnego błędu przypadkowego [patrz paragraf 3, wzór 3.5] i powinien być nie większy niż zastosowany margines CTV-PTV właściwy dla danej lokalizacji. Typowe wartości PPR wynoszą: 1) głowa i szyja: $0,3 \mathrm{~cm}, 2)$ klatka piersiowa: $0,5 \mathrm{~cm}, 3)$ miednica: $0,5 \mathrm{~cm}$. Można PPR określić dla każdej lokalizacji i każdego kierunku oddzielnie. Jest to jednak niepraktyczne i w rutynowej pracy zwykle nie zdaje egzaminu.

W pierwszej sesji terapeutycznej należy wykonać zdjęcia portalowe, o ile to możliwe, dla wszystkich pól terapeutycznych. Obowiązkiem techników jest wzrokowa ocena uzyskanych obrazów, celem zweryfikowania, czy nie popełniono grubego błędu ułożenia oraz, czy kształt pól jest zgodny z planem leczenia. W przypadku stwierdzenia błędu należy wstrzymać realizację napromieniania. Typowe błędy grube to niewłaściwy kształt pola lub niewłaściwy kąt kolimatora. Dalsze postępowanie zależy od tego, czy w zbiorze pól terapeutycznych były takie, dla których ustalono na etapie planowania, że obrazy tych pól będą służyły do oceny ilościowej zgodności ułożenia zrealizowanego i zaplanowanego. Jeżeli w zbiorze pól terapeutycznych są pola zbliżone do pól ortogonalnych należy, z użyciem dedykowanych narzędzi, dopasować obrazy tych pól do odpowiednich obrazów pól referencyjnych. Po nałożeniu obrazów należy liczbowo z użyciem każdej pary komplementarnych obrazów wyznaczyć błędy ułożenia. Oznaczmy błędy ułożenia za pomocą wektora (bx,by,bz). W przeciwnym przypadku, gdy wśród pól terapeutycznych takich pól nie ma, należy wykonać zdjęcia portalowe dla pól weryfikacyjnych i analogicznie poprzez dopasowanie odpowiednich obrazów należy wyznaczyć błąd ułożenia. Jeżeli uzyskany wynik dla każdej składowej wektora błędu (moduł wartości) nie przekracza PPR należy napromienić pacjenta. Jeżeli którakolwiek ze składowych wektora błędu przekracza PPR należy jeszcze raz ułożyć pacjenta, wykonać ponownie zdjęcia portalowe i wyznaczyć błąd ułożenia. Jeżeli uzyskany wynik, dla każdej składowej wektora błędu (moduł wartości), nie przekracza podwojonej wartości PPR należy napromienić pacjenta. Jeżeli natomiast co najmniej jedna składowa błędu ułożenia przekracza 2.PPR należy poinformować lekarza prowadzącego. Zadaniem lekarza prowadzącego jest podjęcie decyzji o dalszym postępowaniu. W drugiej i trzeciej sesji terapeutycznej wykonywane są zdjęcia dla pól odniesienia (wybrane pola terapeutyczne lub pola weryfikacyjne). Jeżeli uzyskany wynik dla każdej składowej wektora błędu (moduł wartości) nie przekracza podwojonej wartości PPR należy napromienić pacjenta. Jeżeli natomiast co najmniej jedna składowa błędu ułożenia przekracza 2.PPR należy poinformować lekarza prowadzącego, którego zadaniem jest podjęcie decyzji odnośnie dalszych kroków. 


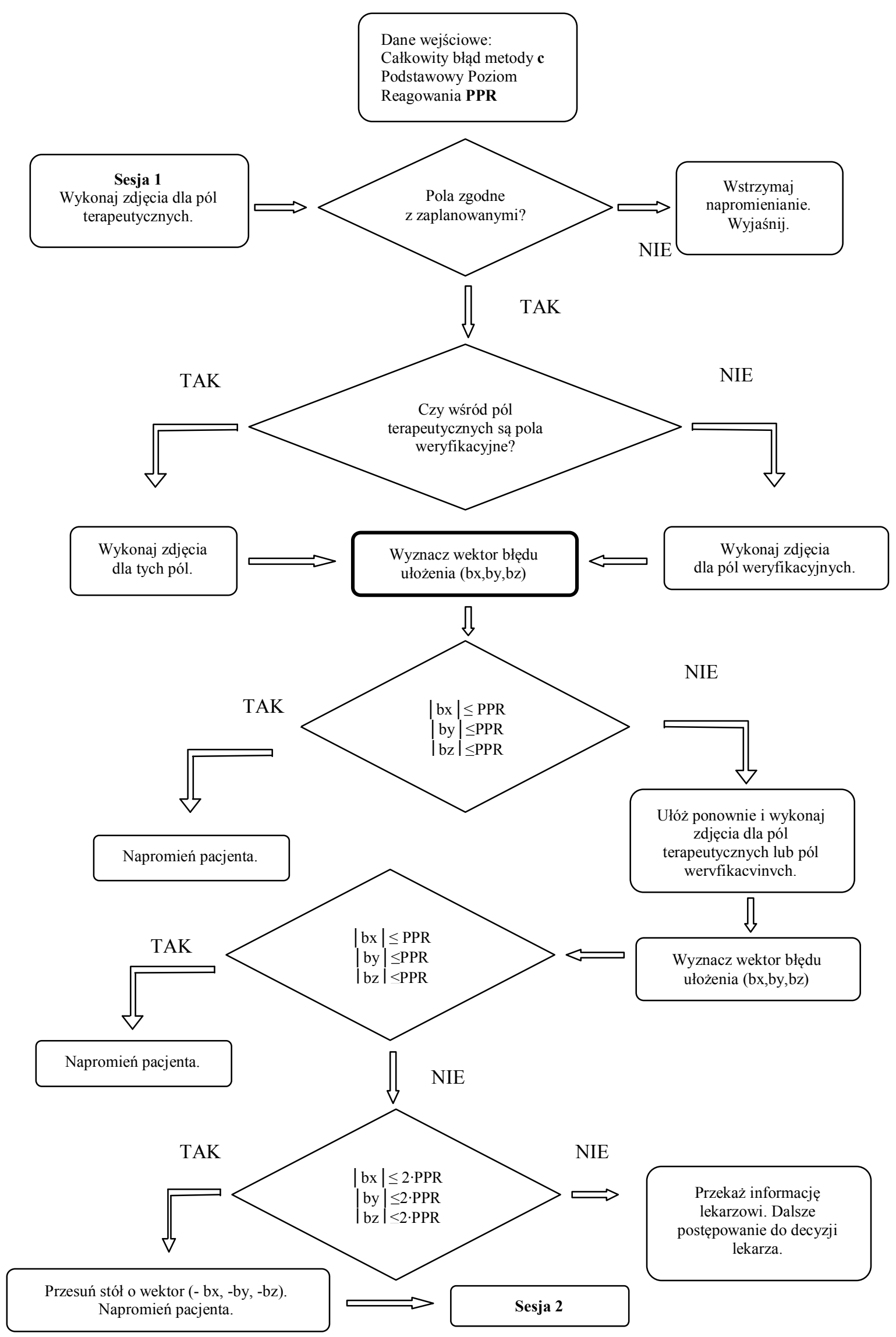

Rycina 8.1. Schemat postępowania w pierwszej sesji terapeutycznej. 


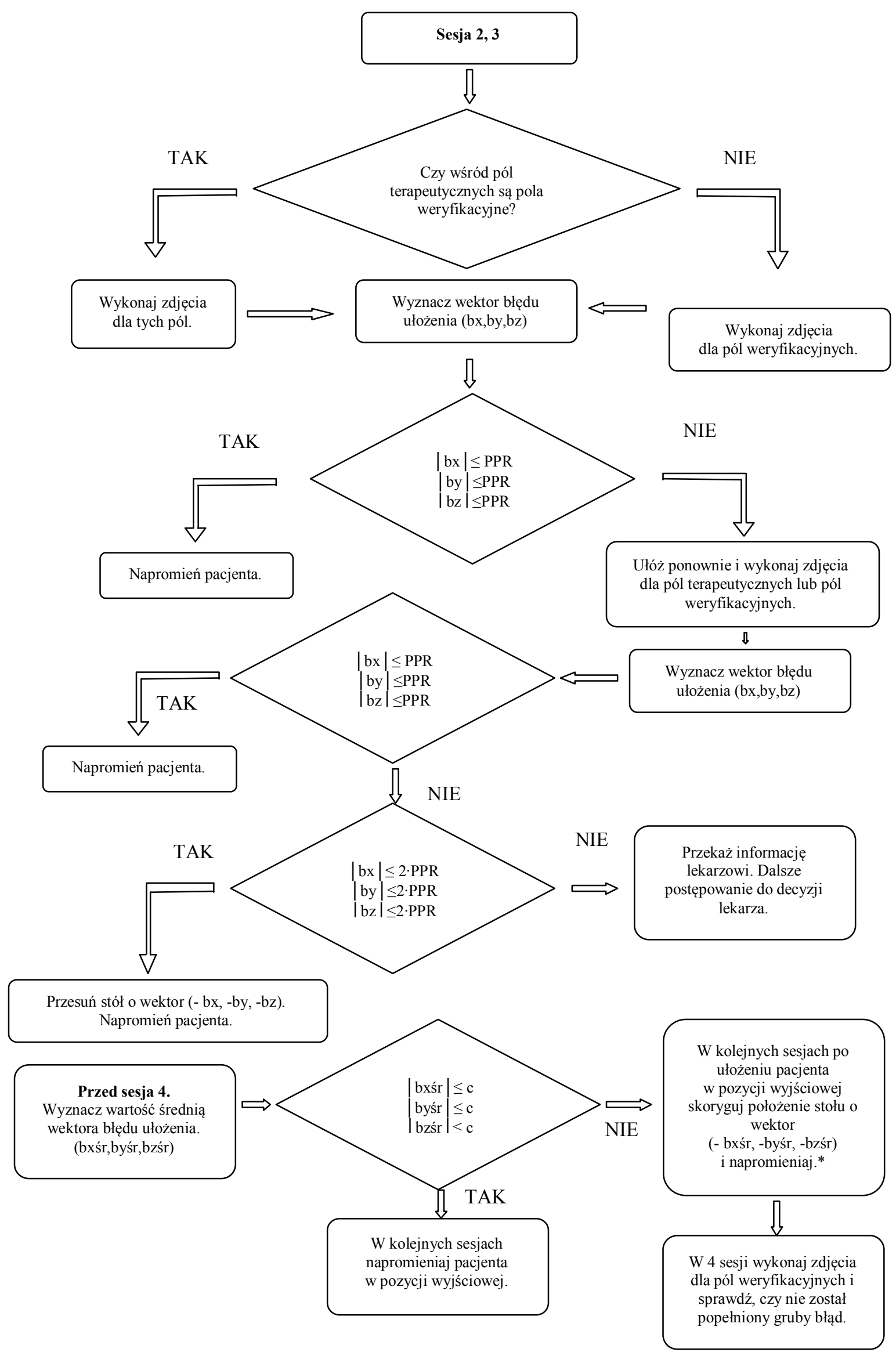

* W przypadku, gdy błąd systematyczny nie przekracza dokładności metody „,” można zrezygnować z korekty ułożenia.

\section{Rycina 8.2. Schemat postępowania $w$ drugiej i trzeciej sesji terapeutycznej.}


Oznaczmy wyznaczone błędy ułożenia przez (bx,by,bz) $\mathrm{k}$ oznacza numer wykonanej kontroli portalowej. W przypadku, gdy podczas sesji terapeutycznej $\mathrm{z}$ jakichś powodów wykonano więcej niż jeden zestaw zdjęć bez wykonywania korekty ułożenia pacjenta należy traktować te zestawy, jako kolejne kontrole portalowe. Z użyciem wyników wszystkich wykonanych zestawów kontroli portalowej, dla każdego kierunku niezależnie, obliczana jest estymata błędu systematycznego oraz błędu przypadkowego:

$s_{v}=\frac{1}{K} \sum_{k=1}^{K} b_{v, k}$

wzór 8.1

gdzie $\mathrm{s}_{\mathrm{v}}$ - błąd systematyczny dla kierunku ,v”, tj. x, y lub z,

$$
p_{v}=\sqrt{\frac{1}{K-1}\left(b_{v, k}-s_{v}\right)^{2}}
$$

wzór 8.2

gdzie $\mathrm{p}_{\mathrm{v}}$ - błąd przypadkowy dla kierunku ,,v".

Jeżeli wartość błędu systematycznego nie przekracza całkowitej, wyznaczonej wcześniej, niepewności określenia błędu ułożenia „c”, pacjent kontynuuje leczenie bez jakichkolwiek korekt w określeniu izocentrum planu leczenia. Jeżeli nie jest znana wartość niepewności określenia błędu ułożenia to można przyjąć, że wynosi ona $2 \mathrm{~mm}$. Jeżeli natomiast wartość błędu systematycznego, dla któregokolwiek kierunku przekracza całkowitą niepewność określenia błędu ułożenia, każdorazowo, w kolejnych sesjach terapeutycznych, po ułożeniu pacjenta w pozycji terapeutycznej pozycja stołu jest korygowana o wektor przeciwny do wektora $\mathrm{S}_{\mathrm{v}}$ dla tego kierunku. Zaleca się, aby przed pierwszą sesją terapeutyczną, w której u pacjenta jest wykonywana korekta izocentrum wykonać dodatkową kontrolę portalową (,portal przed”). Celem tej kontroli jest sprawdzenie, czy nie został popełniony gruby błąd (np. błąd rachunkowy, błędne określenie kierunku korekty) w wyznaczeniu korekty.

Jak już zostało to powiedziane wcześniej podobnie można postępować w odniesieniu do błędów określających rotację pacjenta. Jest to jednak niepraktyczne, gdyż w ogromnej większości sytuacji nie posiadamy narzędzi pozwalających na prostą korektę ułożenia pacjenta. Dlatego zaleca się, aby w przypadku stwierdzenia nieakceptowanej rotacji ponownie ułożyć pacjenta, starając się wyeliminować rotację ciała.

W załączniku do niniejszego opracowania (strony 24-26) proponowany schemat kontroli ułożenia został wyjaśniony na przykładzie kilku przypadków klinicznych.

\section{Analiza zgromadzonych danych}

Dotychczas w zaleceniach przedstawiliśmy proponowany schemat postępowania dla pojedynczych pacjentów. Niemniej ważnym zadaniem zespołu prowadzącego kontrolę ułożenia pacjentów jest analiza gromadzonych danych. Pozwala ona spojrzeć obiektywnie na pracę wszystkich zespołów uczestniczących w przygotowaniu i realizacji napromieniania. Ponadto uzyskane miary błędów systematycznych i przypadkowych są używane do obliczenia marginesu CTV-PTV.
Z użyciem zgromadzonych danych dla jednorodnych grup pacjentów wyznaczany jest populacyjny błąd systematyczny (w grupie pacjentów). To zagadnienie było omówione szczegółowo w pierwszej części tego dokumentu, w paragrafie 3. Przypomnijmy tylko, że dla grupy pacjentów wyznaczane są dwie miary błędu systematycznego. Pierwszą miarą jest wartość średnia po średnich uzyskanych dla pojedynczych pacjentów (błąd systematyczny BS1). Drugi błąd opisuje rozrzut błędów systematycznych w jednorodnej grupie pacjentów i matematycznie ten rozrzut jest obliczany, jako odchylenie standardowe obliczone po wartościach średnich uzyskanych dla pojedynczych pacjentów (błąd BS2). Populacyjny błąd przypadkowy jest obliczany, jako wartość średnia odchyleń standardowych uzyskanych dla pojedynczych pacjentów wchodzących w skład jednorodnej grupy pacjentów.

O czym mówią populacyjne błędy systematyczne i błędy przypadkowe? Najważniejszą informację dostarcza błąd systematyczny BS1 obliczony jako wartość średnia po średnich. Jeżeli w trakcie przygotowania pacjentów do radioterapii i realizacji radioterapii jest popełniany ten sam (lub podobny) błąd ułożenia to wyznaczone BS1 może znamiennie różnić się od zera. Jeżeli tak jest, zespół fizyków powinien podjąć wysiłek ustalenia, co jest przyczyną powstającego błędu systematycznego. Należy poszukiwać takiej przyczyny, która może dotyczyć wszystkich pacjentów, dla których wyznaczono błąd BS1. Jeżeli test statystyczny (test Studenta) wykaże, że wartość średnia po średnich jest znamiennie różna od zera, ale bardzo mała to można zrezygnować $\mathrm{z}$ analizy przyczyn prowadzących do tego błędu. Mała oznacza wartość nie przekraczającą 1,5 mm. Dość trudno wykryć przyczyny błędów o tak małych wartościach.

Błąd systematyczny BS2 w sposób najsilniejszy wpływa na margines CTV-PTV, jaki powinien być zastosowany. Błędy systematyczne w jednorodnej grupie pacjentów mają rozkład normalny. Oznacza to, że dla grupy pacjentów, w której wyznaczony błąd ma wartość $\mathrm{BS} 2 \mathrm{x}, \mathrm{BS} 2_{\mathrm{y}}, \mathrm{BS} 2_{\mathrm{z}}$ odpowiednio dla kierunku x, y dla średnio 5 z 100 leczonych pacjentów izocentrum realizowane będzie średnio przesunięte względem zaplanowanego o wektor $>\left(2 \mathrm{BS} 2_{\mathrm{x}}, 2 \mathrm{BS} 2_{\mathrm{y}}, 2 \mathrm{BS} 2_{\mathrm{z}}\right)$. Widać związek błędu systematycznego BS2 z marginesem jaki należy dodać do CTV, aby utworzyć PTV. Im większy błąd BS2 tym większy margines. Właśnie dlatego tak ważne jest wdrożenie schematu postępowania, który zmniejsza wartość błędu systematycznego. Taki schemat jest rekomendowany w tych zaleceniach. Zasadniczo obserwowane wartości błędu systematycznego BS2 są związane z lokalizacją. Najmniejsze błędy otrzymywane są w rejonie głowy i szyi. Zwykle nie przekraczają $0,2 \mathrm{~cm}$. Większe błędy otrzymywane są w pozostałych lokalizacjach. Przekraczają one $0,2 \mathrm{~cm}$. W ośrodkach, w których zwraca się szczególną uwagę na prawidłowe układanie, w których wdrożone zostały protokoły kontroli ułożenia pacjentów zwykle nie przekraczają $0,3 \mathrm{~cm}$.

Błąd przypadkowy wyznaczony w jednorodnej grupie pacjentów zasadniczo jest odzwierciedleniem pracy zespołów układających pacjentów. Należy jednak pamiętać, że jakość 
pracy techników zależy nie tylko od ich umiejętności i rzetelnego traktowania pracy. Istotnymi czynnikami wpływającymi na jakość pracy jest czas przeznaczony na ułożenie pacjenta i współpraca pomiędzy zespołami przygotowującymi i realizującymi leczenie. Innym ważnym czynnikiem jest świadomość tego, że wyniki odtwarzalności układania pacjentów są analizowane. To silny czynnik. Analizowanie wyników jest formą kontroli. Brak kontroli zawsze powoduje obniżenie jakości działalności. Ze względu na to, że błąd przypadkowy ma charakter losowy, raz izocentrum realizowane jest przesunięte w jedną stronę, innym razem $\mathrm{w}$ drugą stronę błędy o charakterze przypadkowym $\mathrm{w}$ znacznie mniejszym stopniu wpływają na margines CTV-PTV niż błędy systematyczne. Bardziej wnikliwa analiza statystyczna wyników pokazuje, że populacyjne błędy systematyczne powinny mieć wartość zbliżoną do wartości populacyjnych błędów systematycznych BS2.

Wyniki uzyskiwane w jednorodnych grupach pacjentów powinny być regularnie analizowane. Regularnie oznacza, że powinny one być analizowane po zgromadzeniu określonej liczby wyników w jednorodnej grupie pacjentów. Zaleca się, aby wyniki były analizowane po zgromadzeniu odpowiednio dużej liczby wyników, np. wyników dla 30 pacjentów. W jednostkach, w których liczba leczonych pacjentów jest bardzo duża takie wymagane może być trudne do spełnienia. W tych jednostkach analiza danych powinna być analizowana nie rzadziej niż raz na pół roku. Wyniki powinny być analizowane niezależnie w jednorodnych grupach pacjentów. Dodatkowo można rozważyć analizę danych dla jednorodnych grup pacjentów leczonych na poszczególnych urządzeniach terapeutycznych oraz przez poszczególne zespoły techników. Zaleca się, aby wyniki analizy były przedstawiane w postaci graficznej. Ponadto uzyskane wyniki i wnioski wypływające $\mathrm{z}$ uzyskanych wyników powinny być przedstawiane wszystkim grupom zawodowym uczestniczącym w przygotowaniu i realizacji napromieniania, lekarzom, technikom i fizykom medycznym.

Odrębna analiza powinna być przeprowadzana dla pojedynczych wyników, dla których stwierdzono przekroczenie podwójnego Podstawowego Poziomu Reagowania. Przeprowadzanie takich analiz wymaga zgromadzenia odpowiednich informacji. Dlatego zaleca się, aby po uzyskaniu wyniku przekraczającego podwojona wartość PPR zanotować wszystkie informacje umożliwiające określenie przyczyn tak dużej niezgodności pomiędzy realizacją i planem leczenia. Korzystne jest, aby analiza tych przypadków była przeprowadzana w krótkim odstępie czasu po zarejestrowaniu błędu.

\section{Marginesy CTV-PTV i wokół organów ryzyka}

Zgodnie z zaleceniami International Commision on Radiation Units and Measurements (ICRU), powszechnie akceptowanymi w Polsce, przygotowując dane do planowania leczenia należy określić co najmniej dwa obszary: Clinical Target Volume (CTV) i Planning Target Volume (PTV). Obszar PTV powstaje poprzez dodanie odpowiedniego marginesu wokół CTV. Plan leczenia powinien być przygotowywany i zrealizowany w taki sposób, aby z dużym prawdopodobieństwem obszar CTV otrzymał dawkę zlecona przez lekarza radioterapeutę. Temu celowi jest podporządkowane określenie marginesu, jaki należy dodać do CTV. Samo zagadnienie określania marginesu jest niezwykle skomplikowane i wymaga od osób przygotowujących leczenia nie tylko dużej wiedzy, ale również zgromadzenia odpowiednich danych klinicznych.

\subsection{Skladowe marginesu CTV-PTV}

Ogólnie do określenia marginesu CTV-PTV stosowany jest formalizm znany z rachunku błędów, kwalifikujący składowe błędu (niepewności), jako systematyczne i przypadkowe. Błędy systematyczne mają znacznie większy wpływ na wynik radioterapii i dlatego powinny być zawsze uwzględniane w określaniu marginesu CTV-PTV.

Wskazywanych jest wiele różnych źródeł błędu systematycznego. Do najważniejszych składowych o rozkładzie Gaussowskim zalicza się:

$\Sigma_{\text {lek }}$ - błąd systematyczny związany z ograniczoną precyzją wrysowania targetu; jak pokazują liczne publikacje ten błąd może mieć bardzo dużą wartość, jednakże w wielu opracowaniach ten błąd nie jest uwzględniany w określeniu marginesu CTV-PTV.

$\Sigma_{\mathrm{CT}}$ - błąd systematyczny wynikający $\mathrm{z}$ faktu, że obraz tomograficzny pacjenta reprezentuje chwilowe położenie narządów wewnętrznych i związane $\mathrm{z}$ tym położenie targetu; Ten błąd jest niewielki w przypadku radioterapii wykonywanej w rejonie głowy i szyi. W pozostałych lokalizacjach może mieć istotne znaczenie. Niestety, za wyjątkiem gruczołu krokowego brak jest danych literaturowych pozwalających oszacować ten błąd.

$\Sigma_{\text {set-up }}$ - błąd systematyczny ułożenia; Na ten błąd składa się wiele przyczyn. Może zostać wyznaczony poprzez kontrolę ułożenia pacjenta. Wdrożenie protokołu NAL pozwala na znaczące zmniejszenie tego marginesu.

Przyjmując, że wymienione błędy mają charakter Gaussowski wartość całkowita błędu systematycznego jest obliczana, jako pierwiastek z sumy kwadratów:

$$
\Sigma=\sqrt{\left(\Sigma_{l e k}\right)^{2}+\left(\Sigma_{C T}\right)^{2}+\left(\Sigma_{\text {set-up }}\right)^{2}}
$$

wzór 10.1

Dodatkowo źródłem błędu systematycznego może być system planowania leczenia. Wynika to $\mathrm{z}$ faktu ograniczonej dokładności obliczania rozkładu dawki wykonywanej $\mathrm{z}$ użyciem systemu planowania leczenia. Te błędy mają charakter systematyczny, aczkolwiek o różnej wartości w zależności od lokalizacji. Jako przykład błędu systematycznego wnoszonego przez system planowania leczenia można podać wpływ wielkości detektora na pomiar profilu wiązek. Ze względu na niezerową wielkość detektora zmierzony półcień wiązki jest zawsze większy od rzeczywistego półcienia. Błąd wnoszony 
przez system planowania leczenia nie ma charakteru Gaussowskiego, wchodzi do błędu całkowitego liniowo. Oznaczmy ten błąd literą „b”. Wtedy całkowity błąd systematyczny dany jest wyrażeniem:

$\Sigma=\Sigma_{\text {tot }}+b$

wzór 10.2

Warto jednak zauważyć, że liczbowo „b” może mieć wartość ujemną. Z taką sytuacją spotkamy się, w przypadku użycia w pomiarze profili dużego detektora. Profil w obszarze wysokich dawek jest zawężany, co prowadzi do stosowania zbyt dużych pól terapeutycznych.

W każdej sesji terapeutycznej występuje różnica pomiędzy rozkładem dawki zrealizowanym i rozkładem dawki obliczonym. Ta różnica to błąd przypadkowy. Ze względu na losowy charakter tych błędów, ze średnią wartością bliską zeru mają one znacznie mniejszy wpływ na realizację leczenia niż błąd systematyczny. Dlatego błędy przypadkowe w niewielkim stopniu wpływają na wielkość marginesu CTV-PTV.

Wzór stosowany do obliczenia marginesu ma ogólną postać (wzór podano dla jednego kierunku):

$M=k_{\text {syst }} \cdot \Sigma_{\text {tot }}+k_{\text {przyp }} \cdot \sigma_{\text {tot }}$

Wzór 10.3

gdzie $\Sigma_{\text {tot }}$ - całkowity błąd systematyczny, $\sigma_{\text {tot }}$ - całkowity błąd przypadkowy.

Wartości liczbowe współczynników k zależą od tego, w jaki sposób sformułowany został cel wprowadzenia marginesu CTV-PTV. Stroom w swojej pracy twierdzi, że zastosowanie wzoru postaci:

$$
M=2 \cdot \Sigma_{t o t}+0,7 \cdot \sigma_{t o t}
$$

wzór 10.4

pozwala na podanie dawki, nie mniejszej niż 95\% dawki zleconej przez lekarza, w co najmniej 99\% objętości CTV.

Marcel van Herk proponuje wzór:

$M=2,5 \cdot \Sigma_{t o t}+0,7 \cdot \sigma_{t o t}$

wzór 10.5

i twierdzi, że przyjęcie takich wartości współczynników $\mathrm{k}$ pozwala na uzyskanie dawki minimalnej o wartości 95\% u co najmniej 90\% pacjentów, u których zastosowano cytowany wzór do obliczenia marginesu CTV-PTV. Obydwa wzory mają identyczną postać dla każdego kierunku, co oznacza, że margines może mieć różne wartości dla różnych kierunków.

Warto zauważyć, że w obydwu wzorach błąd systematyczny wnosi trzykrotnie lub nawet większy wpływ na margines CTVPTV.

Stosując jeden $\mathrm{z}$ powyższych wzorów należy jeszcze rozstrzygnąć, jaką wartość błędu systematycznego należy użyć do obliczeń. Jak już zaznaczono dość trudno jest oszacować wkład do błędu systematycznego związany z niepewnością wrysowania targetu oraz przygotowaniem planu leczenia $\mathrm{z}$ użyciem zestawu obrazów CT, które nie reprezentują średniego obrazu pacjenta. Dodatkowo wdrożenie systemu No Action Level prowadzi do znaczącego zmniejszenia błędu systematycznego wynikającego $\mathrm{z}$ niepewności ułożenia pacjenta. Po zgromadzeniu trzech wyników kontroli ułożenia, jeżeli tylko błąd systematyczny przekracza precyzję metody, dokonywana jest codziennie kontrola ułożenia pacjenta i tym samym znacząco zmniejszany jest błąd systematyczny. Resztkowy błąd systematyczny jest związany $\mathrm{z}$ błędem przypadkowym i można go wyrazić wzorem:

$\Sigma_{r e s z t}=\frac{\sigma_{t o t}}{\sqrt{K}}$

wzór 10.6

gdzie $\sigma_{\text {tot }}$ to populacyjny błąd przypadkowy a $\mathrm{K}$ to liczba wykonanych kontroli portalowych, które użyto do wyznaczenia błędu systematycznego.

W zalecanym schemacie liczba kontroli wynosi 3, czyli mianownik wynosi 1,73 . Populacyjny błąd systematyczny zwykle nie przekracza $0,3 \mathrm{~cm}$, co jak łatwo policzyć prowadzi do wniosku, że resztkowy błąd systematyczny nie przekracza $0,2 \mathrm{~cm}$.

W rzeczywistości obliczenie marginesu jest zagadnieniem znacznie bardziej złożonym. Wystarczy zauważyć, że na margines wpływa np. geometria napromieniania, odległość pomiędzy przekrojami tomograficznymi, liczba i orientacja wiązek terapeutycznych. Szerokie omówienie niniejszego zagadnienia można znaleźć w publikacji przygotowanej przez British Institute of Radiology pt. Geometric Uncertainties in Radiotherapy. Zastosowanie tych bardzo skomplikowanych formuł do obliczania marginesu jest trudne i ze względu na brak danych wejściowych danych, albo na bardzo dużą ich niepewność, jest niepraktyczne.

Świadomość tych wszystkich ograniczeń wskazuje, że wyniki uzyskane $\mathrm{z}$ kontroli ułożenia pacjenta pozwalają jedynie na ograniczenie $z$ dołu marginesu, jaki powinien być dodawany do CTV.

Jeżeli stosujemy schemat NAL to w obliczeniach mamy prawo, w miejsce wyznaczonego błędu systematycznego, określonego z użyciem wyników kontroli ułożenia uzyskanych w pierwszych trzech sesjach terapeutycznych, użyć resztkowego systematyczny błędu populacyjnego oraz błąd metody. Jeżeli dla błędu metody znane jest odchylenie standardowe to należy traktować obydwa błędy jako niezależne, o rozkładzie normalnym. Matematycznie oznacza to, że całkowity błąd systematyczny można obliczyć ze wzoru:

$\Sigma_{\text {tot }}=\sqrt{\left(\Sigma_{\text {reszt }}\right)^{2}+\left(\Sigma_{\text {metody }}\right)^{2}}$

wzór 10.7

gdzie $\Sigma_{\text {metody }}$ to odchylenie standardowe wyrażające błąd metody. Często błąd metody jest określany z zastosowaniem ciągłego rozkładu jednostajnego, czyli ten błąd jest wyrażany poprzez stwierdzenie, błąd nie jest większy niż c lub prawdziwa wartość wyniku znajduje się w przedziale [-c,c]. W takiej sytuacji należy obliczyć odchylenie standardowe dla takiego rozkładu i tak obliczoną wartość użyć, jako $\Sigma_{\text {metody }}$.

$$
\Sigma_{\text {metody }}=\frac{c}{\sqrt{3}}
$$

wzór 10.8

Obliczmy minimalną wartość marginesu dla terapii pacjenta leczonego $\mathrm{w}$ rejonie głowy $\mathrm{i}$ szyi. W przykładzie analizowanym $\mathrm{w}$ poprzednim paragrafie błąd metody wynosi 
0,17 cm. Przyjmijmy, że jest to jedno odchylenie standardowe. Populacyjny błąd systematyczny wyznaczony w ośrodku wyniósł $0,15 \mathrm{~cm}$, natomiast przypadkowy błąd populacyjny wyniósł $0,18 \mathrm{~cm}$. Całkowity błąd systematyczny wynosi:

$\Sigma_{\text {tot }}=\sqrt{(0,18 / 3)^{2}+(0,17)^{2}}=0,18 \mathrm{~cm}$

Ze wzoru Strooma otrzymujemy minimalna wartość marginesu wynosi:

$\left(M_{C T V-P T V}\right)_{\min }=2,0 \cdot 0,18+0,7 \cdot 0,18=0,48 \mathrm{~cm}$.

Ostateczna decyzja o wielkości marginesu powinna zostać podjęta arbitralnie, jednakże margines nie powinien być mniejszy od $0,48 \mathrm{~cm}$, w praktyce $0,50 \mathrm{~cm}$.

W pewnych sytuacjach może się okazać, że przygotowanie planu leczenia spełniającego wymagane kryteria nie jest możliwe, ze względu na zbyt wysokie dawki absorbowane przez narządy krytyczne. W takiej sytuacji decyzja o dalszym sposobie postępowania należy do lekarza prowadzącego.

Jest oczywiste, że podobnie jak dla guza nowotworowego, również dla narządów ryzyka zapewnienie właściwej ochrony tych narząów przed uszkodzeniem wymaga, aby w trakcie planowania leczenia uwzględnić niepewność przygotowania i realizacji radioterapii. Takie postępowanie ma szczególne znaczenie w przypadku narządów zbudowanych szeregowo, dla których istnieje korelacja pomiędzy zaabsorbowaną w nich dawką maksymalną i prawdopodobieństwem uszkodzenia. W jedynej opublikowanej na ten temat pracy, której pierwszym autorem jest McKenzie autorzy zaproponowali, aby margines wokół narządu obliczać ze wzoru:

$M=1,3 \cdot \Sigma_{t o t}+0,5 \cdot \sigma_{t o t}$

wzór 10.9

We wzorze użyto tych samych oznaczeń, jakich użyto do opisu marginesu dla targetu. W tej samej pracy wskazuje się, wzór można również stosować do małych narządów zbudowanych równolegle, np. ślinianek.

\section{Podsumowanie}

Kontrola ułożenia pacjenta jest jednym $\mathrm{z}$ najważniejszych elementów kontroli jakości napromieniania. Należy podkreślić jeszcze raz, że błędy w określeniu dawki, jeżeli wykryte na wczesnym etapie leczenia, w wielu przypadkach mogą zostać skorygowane. Błędy geometryczne można skorygować sporadycznie. Dobrze prowadzona kontrola ułożenia pacjentów wymaga jasnego i precyzyjnego określenia sposobu jej przeprowadzania, w tym w szczególności należy ustalić, jaki schemat kontroli zostanie wdrożony. Nowoczesne rozwiązania technologiczne znacząco ułatwiają prowadzenie kontroli. Niemniej nigdy nie wolno zapomnieć o wykonaniu przynajmniej jakościowej analizy portalu dla każdego pola terapeutycznego. Nowoczesne rozwiązania, takie jak „Cone Beam CT”, zachęcające do stosowania ich on-line, niosą ze sobą niebezpieczeństwo niechlujnej pracy - po wykonaniu kontroli skorygujemy położenie pacjenta. Takie postępowanie jest niewłaściwe. Kontrola ma jedynie potwierdzać wyniki naszych wysiłków, w celu uzyskania zaplanowanej pozycji terapeutycznej. Uzyskane wyniki $\mathrm{z}$ kontroli portalowej powinny być regularnie analizowane, podobnie jak to ma miejsce $\mathrm{w}$ analizie zdjęć odrzuconych $\mathrm{w}$ radiologii $\mathrm{rtg}$. Kontrola ułożenia pacjenta jest soczewką, w której skupiają się wszystkie kroki procedury radioterapeutycznej, od przygotowania planu leczenia do realizacji i właśnie dlatego ten rodzaj kontroli powinien być przeprowadzany z dużą starannością.

\section{Literatura}

[1] Balter JM, Sandler HM, Lam K, et al. Measurement of prostate movement over the course of routine radiotherapy using implanted markers. Int J Radiat Oncol Biol Phys. 1995;31(1):113-118.

[2] Bel A, Bartelink H, Vijbrief RE, et al. Transfer errors of planning CT to simulator: a possible source of set up inaccuracies? Radiother Oncol. 1994;31(2):176-180.

[3] Bel A, van Herk M, Lebesque JV. Target margins for random geometrical treatment uncertainties in conformal therapy. Med Phys. 1996;23(9):1537-1545.

[4] de Boer HC, Heijmen BJ. eNAL: An extension of the NAL setup correction protocol for effective use of weekly followup measurements. Int J Radiat Oncol Biol Phys. 2007;67(5):1586-1595.

[5] Ekberg L, Holmberg O, Wittgren L, at al. What margins should be added to the clinical target volume in radiotherapy treatment planning for lung cancer? Radiother Oncol. 1998;48(1):71-77.

[6] El-Gayed AAH, Bel A, Vijlbrief RE, et al. Time trend of patient setup deviations during pelvic irradiation using electronic portal imaging. Radiother Oncol. 1993;26(2):162-171.

[7] Herman MG, Balter JM, Jaffray DA, et al. Clinical use of electronic portal imaging: report of AAPM Radiation Therapy Committee Task Group 58. Med Phys. 2001;28(5):713-734.

[8] Hurkmans CW, Remeijer P, Lebesque JV, et al. Set-up verification using portal imaging : review of current clinical practice. Radiother Oncol. 2001;58(2):105-120.

[9] International Commission on Radiation Units and Measurements. ICRU Report 50. Prescribing, recording and reporting photon beam therapy. Bethesda, MD: ICRU, 1993. 
[10] International Commission on Radiation Units and Measurements. ICRU Report 62. (Supplement to ICRU Report 50). Prescribing, recording and reporting photon beam therapy. Bethesda, MD: ICRU, 1999.

[11] Jaffray DA, Siewerdsen JH, Wong JW, et al. Flat- panel cone-beam computed tomography for image-guided radiation therapy. Int J Radiat Oncol Biol Phys. 2002:53(5):1337-1349.

[12] Geometric Uncertainties in radiotherapy, Defining the Planning Target Volume. The British Institute of Radiology, 2003.

[13] McKenzie AL, van Herk M, Mijnheer B. The width of margins in radiotherapy treatment plans. Phys Med Biol. 2000; 45(11):3331-3342.

[14] McKenzie AL. How should breathing motion be combined with other errors when drawing margins around clinical target volumes? Br J Radiol. 2000;73(873):973-977.

[15] McKenzie AL, van Herk M, Mijnheer B. Margins for geometric uncertainty around organs at risk in radiotherapy. Radiother Oncol. 2002;62(3):299-307.

[16] Penninkhof J, Quint S, Baaijens M, et al. Practical use of the extended no action level (eNAL) correction protocol for breast cancer patients with implanted surgical clips. Int J Radiat Oncol Biol Phys. 2012;82(2):1031-1037.

[17] Remeijer P, Rasch C, Lebesque JV, et al. A general methodology for 3D analysis of variation in target volume delineation. Med Phys. 1999;26(6):931-940.

[18] Samson MJ, van Sörnsen de Koste JR, de Boer HCJ, et al. An analysis of anatomic landmark mobility and setup deviations in radiotherapy for lung cancer. Int J Radiat Oncol Biol Phys. 1999;43(4):827-832.

[19] Stroom JC, de Boer HC, Huizenga H, et al. Inclusion of geometrical uncertainties in radiotherapy treatment planning by means of coverage probability. Int J Radiat Oncol Biol Phys. 1999;43(4):905-919.

[20] de Boer HC, Heijmen BJ. eNAL: An extension of the NAL setup correction protocol for effective use of weekly followup measurements. Int J Radiat Oncol Biol Phys. 2007;67(5):1586-1595.

[21] Stroom J, Gilhuijs K, Viera S, at al. Combined Recipe for Clinical target Volume and Planning Target Volumes. Int J Radiat Oncol Biol Phys. 2014;88(3):708-714.

[22] van Elmpt W, McDermott L, Nijsten S, et al. A literature review of electronic portal imaging for radiotherapy dosimetry. Radiother Oncol. 2008;88(3):289-309.

[23] van Herk M, Remeijer P, Rasch C, et al. The probability of correct target dosage: dose - population histograms for deriving treatment margins of radiotherapy. Int J Radiat Oncol Biol Phys. 2000;47(4):1121-1135.

[24] van Herk M. Errors and margins in radiotherapy. Semin Radiat Oncol. 2004;14(1):52-64.

[25] Verellen D, De Ridder M, Tournel K, et al. An overview of volumetric imaging technologies and their quality assurance for IGRT. Acta Oncologica. 2008; 47(7): 1271-1278. 


\section{Załącznik - przykłady}

\section{Przykład 1. Rejon glowy i szyi.}

\section{Dane wejściowe}

Wyznaczony całkowity błąd kontroli portalowej wynosi 0,12 $\mathrm{cm}$. Podstawowy Poziom Reagowania 0,30 cm. Margines CTV-PTV wynosi $0,50 \mathrm{~cm}$.

\section{Geometria}

Pacjent jest napromieniany 5 polami z kątów $10^{\circ}, 80^{\circ}, 100^{\circ}$, $165^{\circ}$ i $300^{\circ}$. Zadecydowano, że pola z kątów $10^{\circ}$ i $100^{\circ}$ będą traktowane, jako pola weryfikacyjne. Dla tych pól wykonano rekonstrukcje radiograficzne.

\section{Sesja nr 1}

Wykonano zdjęcia portalowe dla każdego pola terapeutycznego. Po wzrokowym porównaniu $\mathrm{Z}$ rekonstrukcjami radiograficznymi nie stwierdzono żadnych istotnych rozbieżności pomiędzy polami realizowanymi i zaplanowanymi. Następnie dopasowano zdjęcia portalowe $\mathrm{z}$ użyciem struktur typu podstawowego i wyznaczono błąd ułożenia. Uzyskano następujące wyniki: 1) dla pola $10^{\circ}$ $\left(0,3 ;\right.$ brak;0,2), 2) dla pola $100^{\circ}$ (brak;-0,2;0,2). ("Brak wyniku", wynika z faktu, że ze zdjęcia płaskiego można wyznaczyć tylko dwie składowe błędu. Brakującą składową w dalszej części tekstu oznaczono, jako „brak”). Nie stwierdzono istotnych rotacji ciała pacjenta. Po porównaniu uzyskanych wyników z przyjętym PPR nie stwierdzono przekroczenia PPR w żadnym kierunku. Dlatego zgodnie ze schematem postępowania podjęto decyzję o kontynuowaniu leczenia bez jakichkolwiek zmian w ułożeniu pacjenta.

\section{Sesja nr 2}

Napromienianie rozpoczęto od pól z kątów $10^{\circ}$ i $100^{\circ} \mathrm{W}$ celu zweryfikowania poprawności ułożenia pacjenta. Następnie dopasowano zdjęcia portalowe i wyznaczono błąd ułożenia. Podobnie, jak w sesji pierwszej nie stwierdzono rotacji ciała pacjenta. Uzyskano następujące wyniki: 1) dla pola $10^{\circ}$ $\left(0,2 ;\right.$ brak;0,4), 2) dla pola $100^{\circ}$ (brak;-0,2;0,3). Po porównaniu uzyskanych wyników $\mathrm{z}$ przyjętym PPR nie stwierdzono przekroczenia 2PPR w żadnym kierunku. Dlatego zgodnie ze schematem postępowania napromieniono pacjenta $z$ pozostałych pól i podjęto decyzję o kontynuowaniu leczenia bez jakichkolwiek zmian w ułożeniu pacjenta.

\section{Sesja nr 3}

Powtórzono sekwencję działań taką, jak w sesji drugiej. Nie stwierdzono rotacji ciała. Jednakże po wykonaniu zdjęcia $\mathrm{z}$ pola $10^{\circ}$ uzyskano wyniki $(0,2 ;$ brak;0,5). Dla składowej $\mathrm{z}$ przekroczony jest 2PPR. Dlatego ponownie ułożono pacjenta $\mathrm{w}$ pozycji terapeutycznej i powtórzono zdjęcie $\mathrm{z}$ pola $10^{\circ}$. Uzyskano wynik $(0,2 ;$ brak;0,4). Ze względu na to, że nie stwierdzono przekroczenia PPR wykonano zdjęcie portalowe dla pola $100^{\circ}$. Dla tego pola uzyskano wynik (brak;-0,2;0,3). W tym przypadku również nie został przekroczony PPR. Uzyskane wyniki dla obydwu pól nie wykazały rotacji ciała pacjenta. Napromieniono pacjenta z pozostałych pól.

Przed czwartą sesją terapeutyczną obliczono wektor korekty, jako wartość średnią z uzyskanych wyników, tj. dla kierunku x:

$(0,3+0,2+0,2+0,2) / 4=0,23 \mathrm{~cm} \approx 0,2 \mathrm{~cm}$,

dla kierunku y:

$(-0,2+(-0,2)+(-0,2)) / 3=-0,20 \mathrm{~cm} \approx-0,2 \mathrm{~cm}$

dla kierunku z:

$(0,2+0,2+0,4+0,3+0,5+0,4) / 6=0,33 \mathrm{~cm} \approx 0,3 \mathrm{~cm}$

Wyniki zaokrąglono, gdyż translacja stołu terapeutycznego jest możliwa jedynie w całkowitych dziesiątych częściach centymetra.

Ze względu na to, że dla kierunku z błąd systematyczny przekracza całkowity błąd metody podjęto decyzję o korygowaniu w kolejnych sesjach terapeutycznych położenia stołu o wektor $(0,0 ; 0,0 ;-0,3)$.

\section{Sesja czwarta}

Po ułożeniu pacjenta skorygowano jego ułożenie o wektor $(0,0 ; 0,0 ;-0,3)$. Napromienianie rozpoczęto od pól z kątów $10^{\circ} \mathrm{i}$ $100^{\circ} \mathrm{w}$ celu zweryfikowania poprawności ułożenia pacjenta. Wykonano zdjęcie sprawdzające $\mathrm{z}$ pola $10^{\circ} \mathrm{i}$ określono błąd ułożenia. Uzyskano wynik $(0,0 ;$ brak;0,1). Wykonano zdjęcie sprawdzające z pola $100^{\circ}$ i określono błąd ułożenia. Uzyskano wynik (brak;-0,1;0,0). Uzyskane wyniki nie wykazały, że popełniono błąd $\mathrm{w}$ określaniu wektora korekcji i podjęto decyzję o kontynuowaniu leczenia.

Ze względu na to, że po 17 frakcjach technicy stwierdzili „luz” w masce podjęto decyzję o wykonaniu zdjęć weryfikacyjnych w 18 frakcji. Wykonano zdjęcie sprawdzające z pola $10^{\circ}$ i określono błąd ułożenia. Uzyskano wynik $\left(0,1\right.$;brak;-0,2). Wykonano zdjęcie sprawdzające $\mathrm{z}$ pola $100^{\circ} \mathrm{i}$ określono błąd ułożenia. Uzyskano wynik (brak;-0,1;-0,1). Uzyskany wynik nie wskazywał na to, że schudnięcie pacjenta prowadzi do pogorszenia odtwarzalności leczenia. Dlatego kontynuowano leczenia bez wykonywania jakichkolwiek dodatkowych kontroli. 


\section{Przykład 2. Napromienianie pacjentki $z$ nowotworem sutka po zachowawczej operacji.}

\section{Dane wejściowe}

Wyznaczony całkowity błąd kontroli portalowej wynosi 0,18 $\mathrm{cm}$. Margines CTV-PTV wynosi $0,80 \mathrm{~cm}$. Podstawowy Poziom Reagowania $0,50 \mathrm{~cm}$.

\section{Geometria}

Pacjentka napromieniana dwoma polami tangencjalnymi $\mathrm{z}$ kątów $312^{\circ}$ i $134^{\circ}$. Zadecydowano, że pola od boku, z kąta $134^{\circ}$ oraz dodatkowe pole weryfikacyjne $\mathrm{z}$ kąta $0^{\circ}$ będą polami weryfikacyjnymi. Wymiary pola $\mathrm{z}$ kąta $0^{\circ}$ dobrano tak, aby granica boczna przekraczała o $1 \mathrm{~cm}$ linię środkową na stronę przeciwną do napromienianej. Takie pole uwidacznia struktury mostka. Dla tych pól wykonano rekonstrukcje radiograficzne.

\section{Sesja nr 1}

Wykonano zdjęcia portalowe dla obydwu pól terapeutycznych. Po wzrokowym porównaniu z rekonstrukcjami radiograficznymi nie stwierdzono żadnych istotnych rozbieżności pomiędzy polami realizowanymi i zaplanowanymi. Następnie dopasowano zdjęcie portalowe $\mathrm{z}$ kąta $134^{\circ} \mathrm{z}$ użyciem struktur typu podstawowego i wyznaczono błąd ułożenia. Uzyskano następujące wynik: (brak;-0,4;-0,7). Zdjęcie wykazało niewielką rotację ciała pacjentki. Ze względu na to, że dla kierunku z błąd przekroczył PPR jeszcze raz ułożono pacjentkę i wykonano jeszcze raz zdjęcie portalowe. Uzyskano następujący wynik (brak;0,3;$0,7)$. W kierunku $\mathrm{z}$ ponownie przekroczony został PPR, jednakże wartość ta nie przekracza 2PPR. Wykonano zdjęcie portalowe dla pola $\mathrm{z}$ kąta $314^{\circ}$ i uzyskano błąd $(-0,4 ;$ brak;-0,6). To zdjęcie potwierdziło istnienie błędu ułożenia w kierunku głowa-nogi, ale błąd nie przekraczał 2PPR. Ze względu jednak na to, że błąd w kierunku z przekroczył PPR skorygowano położenie stołu o wektor $(0,4 ; 0,4 ; 0,6)$ i napromieniono pacjentkę z obydwu pól (arbitralnie przyjęto dla kierunku z przesunięcie o wartość 0,6 ).

Warto zauważyć, że wybór pola weryfikacyjnych, które wybrano nie są polami prostopadłymi, co skutkuje tym, iż tylko kierunek z jest reprezentowany na obydwu zdjęciach. W istocie kierunki x $\mathrm{i}$ y (pierwsza $\mathrm{i}$ druga współrzędna) dostarczają trochę innych informacji. Pacjentka jest napromieniana dwoma polami przeciwległymi (niemal przeciwległymi). Do kontroli ułożenia wystarczające byłoby wykonanie zdjęcia tylko dla jednego pola $\mathrm{z}$ tym zastrzeżeniem, że wykrycie błędu polegającego na przesunięciu punktu izocentrycznego wzdłuż osi centralnej wiązki (kierunek wertykalny) byłoby bardzo trudne do wykrycia. Dodanie drugiego pola $\mathrm{z}$ kąta $0^{\circ}$ pozwala na ocenę zmiany położenia punktu izocentrycznego na kierunku lewo-prawo, co pośrednio wskazuje na błąd w kierunku równoległym do osi centralnej wiązek terapeutycznych.

\section{Sesja nr 2}

Napromienianie rozpoczęto od wykonania zdjęcia portalowego z kąta $134^{\circ}$. Po dopasowaniu zdjęcia portalowego i rekonstrukcji radiograficznej uzyskano błąd ułożenia o wartości (brak;-0,2;-0,8). Nie stwierdzono rotacji ciała pacjenta. Nie został przekroczony podwojony PPR, ale przekroczony został PPR. Dlatego ułożono jeszcze raz pacjentkę i powtórzono zdjęcie portalowe. Uzyskano identyczny wynik (brak;-0,2;-0,8). Wykonano zdjęcie dla drugiego pola weryfikacyjnego. Uzyskano wynik $(-0,3$; brak; 0,6 ). Tutaj podobnie nie stwierdzono przekroczenia 2PPR. Podobnie, jak w pierwszej sesji skorygowano położenie stołu o wektor $(0,3 ; 0,2 ; 0,7)$ i napromieniono pacjentkę z obydwu pól.

\section{Sesja nr 3}

Napromienianie rozpoczęto od wykonania zdjęcia portalowego z kąta $134^{\circ}$. Po dopasowani zdjęcia portalowe i rekonstrukcji radiograficznej uzyskano błąd ułożenia o wartości (brak;0,1;1,1). Nie stwierdzono rotacji ciała pacjenta. Dla kierunku z przekroczony został podwojony Podstawowy Poziom Reagowania. Powiadomiono lekarza prowadzącego, przekazując mu wyniki i analizę wyników uzyskanych w pierwszych trzech sesjach terapeutycznych. W porozumieniu $\mathrm{z}$ lekarzem podjęta została decyzja, aby skorygować pozycję stołu przesuwając go w kierunku z o odległość 0,7 i wykonać zdjęcie portalowe dla drugiego pola. Dla drugiego pola weryfikacyjnego uzyskano wynik (-0,3;brak;0,1). Przyjęto, że $\mathrm{w}$ kierunku $\mathrm{z}$, gdyby nie wykonywano przesunięcia stołu uzyskanoby wynik $(-0,3 ;$ brak;-1,0=-1,1+0,1).Uzyskany wyniki potwierdził zasadność podjętych decyzji. Dlatego napromieniono pacjentkę z obydwu pól.

Przed czwartą sesją terapeutyczną obliczono wektor korekty, jako wartość średnią z uzyskanych wyników, tj. dla kierunku z: $((-0,7)+(-0,7)+(-0,6)+(-0,8)+(-0,8)+(-0,6)+$ $+(-1,1)+(-0,6)) / 8=-0,73 \mathrm{~cm} \approx-0,7 \mathrm{~cm}$ dla kierunku y $\mathrm{z}$ dla pola $\mathrm{z}$ kąta $134^{\circ}$ : $(0,4+0,3+(-0,2)+(0,1)) / 4=0,08 \mathrm{~cm} \approx 0,1$

dla kierunku $\mathrm{x}$ dla pola $\mathrm{z}$ kąta $0^{\circ}$ : $((-0,4)+(-0,3)+(-0,3)+(-0,3)) / 4=-0,32 \mathrm{~cm} \approx-0,3 \mathrm{~cm}$, Wyniki zaokrąglono, gdyż translacja stołu terapeutycznego jest możliwa jedynie w całkowitych dziesiątych częściach centymetra.

Ze względu na to, że dla kierunku z błąd systematyczny przekracza całkowity błąd metody podjęto decyzję o korygowaniu położenia stołu $\mathrm{w}$ kierunku x (lateral) o wektor 0,3 oraz w kierunku z (longitudinal) o wektor $0,7 \mathrm{~cm}$, czyli o wektor $(0,3 ; 0,0 ; 0,7)$.

\section{Sesja nr 4}

Po ułożeniu pacjentki skorygowano położenie stołu o wektor $(0,3 ; 0,0 ; 0,7)$. Napromienianie rozpoczęto od wykonania kontroli portalowej dla pola weryfikacyjnego z kąta $0^{\circ}$. Uzyskano wynik $(0,2 ;$ brak; 0,1$)$. Uzyskany wynik po korekcie wykazał, że nie popełniono grubego błędu. Podjęto decyzję o kontynuowaniu leczenia, tj. napromienieniu pacjentki z pól terapeutycznych. Postępując rygorystycznie (zgodnie ze schematem postępowania) należałoby wykonać dodatkowo zdjęcie portalowe dla kąta $134^{\circ}$ lub wykonać zdjęcie portalowe w czasie napromieniania. Jednakże zdecydowano o rezygnacji $\mathrm{z}$ wykonania tego zdjęcia. 


\section{Przykład 3. Napromienianie pacjentki $z$ nowotworem trzonu macicy.}

\section{Dane wejściowe.}

Wyznaczony całkowity błąd kontroli portalowej wynosi 0,17 $\mathrm{cm}$. Margines CTV-PTV wynosi $1,0 \mathrm{~cm}$. Podstawowy Poziom Reagowania wynosi $0,6 \mathrm{~cm}$.

\section{Geometria}

Pacjentka jest napromieniana techniką box. W tym przypadku, jako pola weryfikacyjne przyjęto pole AP $\left(z\right.$ kąta $\left.0^{\circ}\right)$ i pole boczne (z kąta $90^{\circ}$ ).

\section{Sesja nr 1}

Wykonano zdjęcie portalowe dla pola AP. Porównano kształt pola z polem zaplanowanym. Uzyskano wynik $(0,3 ;$ brak;0;4). Nie stwierdzono żadnych istotnych rozbieżności pomiędzy polem realizowanym i zaplanowanym. Wykonano zdjęcie portalowe dla pola bocznego, ze strony lewej. Uzyskano wynik (brak;0,8;0;5). Ze względu na to, że w kierunku y (kierunek wertykalny) przekroczony został PPR jeszcze raz ułożono pacjentkę i ponownie wykonano zdjęcie portalowe. Uzyskano wynik (brak;0,7;0,4). W żadnym kierunku nie został przekroczony podwójny Podstawowy Poziom Reagowania kontynuowano napromienianie. Dla dwóch pozostałych pól PA i z boku, drugie strony wykonano kontrolę portalową. Nie stwierdzono żadnych istotnych rozbieżności pomiędzy polami realizowanymi i zaplanowanymi. Żadne zdjęcie portalowe nie wykazało rotacji pacjentki.

\section{Sesja nr 2}

Postępowano tak, jak w sesji pierwszej. Dla pola AP uzyskano wynik (-0,4;brak;0,2). Wykonano zdjęcie dla pola bocznego, ze strony prawej. Uzyskano wynik (brak;1,0;0,3). Stwierdzono rotację wskazującą na inne ułożenie nóg. $Z$ tego powodu, oraz $\mathrm{z}$ powodu, że dla kierunku y został przekroczony PPR ponownie ułożono pacjentkę, dbając szczególnie o właściwe ułożenie nóg. Wykonano zdjęcie portalowe i uzyskano wynik (brak;0,8;0,4). Nie stwierdzono rotacji. Ze względu na to, że dla żadnego kierunku nie został przekroczony podwojony PPR kontynuowano napromienianie.

\section{Sesja nr 3}

Postępowano tak, jak w sesji pierwszej i drugiej. Dla pola AP uzyskano wynik $(0,2 ;$ brak;0,4). Wykonano zdjęcie dla pola bocznego ze strony lewej. Uzyskano wynik (brak;1,4;0,4). Dla żadnego pola nie stwierdzono rotacji. Ze względu na przekroczenie podwojonego PPR w kierunku wertykalnym wstrzymano napromienianie i powiadomiono lekarza. Lekarz radioterapeuta poprosił o konsultację fizyka medycznego i technika pracującego na tomografie komputerowym. Po uważnej analizie stwierdzono, że w trakcie układania technicy najprawdopodobniej błędnie ustawili odległość od stołu (kierunek wertykalny). Ponownie ułożono pacjentkę i po wykonaniu zdjęcia portalowego uzyskano wynik (brak;0,7;0,3). Lekarz zadecydował, aby przed podaniem dawki terapeutycznej skorygować wysokość stołu o $0,7 \mathrm{~cm}$. Napromieniono pacjentkę ze wszystkich pól.
Przed czwartą sesją terapeutyczną obliczono wektor korekty, jako wartość średnią z uzyskanych wyników, tj.

dla kierunku z:

$(0,4+0,5+0,4+0,2+0,3+0,4+0,4+0,3) / 8=0,36 \approx 0,4$

dla kierunku y :

$(0,8+0,7+(1,0)+(0,8)+0,7) / 4=0,80 \mathrm{~cm} \approx 0,8$

dla kierunku x dla pola $\mathrm{z}$ kąta $0^{\circ}$ :

$(0,3+(-0,4)+(0,2)) / 3=0,03 \mathrm{~cm} \approx 0,0 \mathrm{~cm}$.

\section{Sesja nr 4}

Ze względu na to, że dla kierunku z i y błąd systematyczny przekracza całkowity błąd metody podjęto decyzję o korygowaniu położenia stołu $\mathrm{w}$ kierunku z (longitudinal) o wektor $(-0,4)$ oraz w kierunku y (vertical) o wektor $(-0,8) \mathrm{cm}$, czyli o wektor $(-0,4 ;(-0,8) ; 0,0)$.

Napromienianie rozpoczęto od wykonania kontroli portalowej dla pola weryfikacyjnego z kąta $0^{\circ}$. Uzyskano wynik $(0,2 ;$ brak;0,1). Uzyskana wynik po korekcie wykazał, że nie popełniono grubego błędu. Podjęto decyzję o kontynuowaniu leczenia, tj. napromienieniu pacjentki z pól terapeutycznych. Postępując bardzo rygorystycznie należałoby wykonać dodatkowo zdjęcie portalowe dla pola bocznego lub wykonać zdjęcie portalowe w czasie napromieniania. U tej pacjentki, że względu na zaobserwowane dość duży rozrzut wyników w kierunku lewo-prawo oraz na zaobserwowany duży błąd systematyczny w kierunku wertykalnym postanowiono wykonywać kontrole portalową raz w tygodniu. 